University of Louisville

ThinkIR: The University of Louisville's Institutional Repository

$5-2020$

\title{
Gender-differential effects of perceived discrimination on lawyers' job satisfaction: a general strain theory approach.
}

Caroline Isabelle Jalain

University of Louisville

Follow this and additional works at: https://ir.library.louisville.edu/etd

Part of the Courts Commons, and the Criminology and Criminal Justice Commons

\section{Recommended Citation}

Jalain, Caroline Isabelle, "Gender-differential effects of perceived discrimination on lawyers' job satisfaction: a general strain theory approach." (2020). Electronic Theses and Dissertations. Paper 3411. https://doi.org/10.18297/etd/3411

This Doctoral Dissertation is brought to you for free and open access by ThinkIR: The University of Louisville's Institutional Repository. It has been accepted for inclusion in Electronic Theses and Dissertations by an authorized administrator of ThinkIR: The University of Louisville's Institutional Repository. This title appears here courtesy of the author, who has retained all other copyrights. For more information, please contact thinkir@louisville.edu. 


\title{
GENDER-DIFFERENTIAL EFFECTS OF PERCEIVED DISCRIMINATION ON \\ LAWYERS' JOB SATISFACTION: A GENERAL STRAIN THEORY APPROACH
}

\author{
By \\ Caroline Isabelle Jalain \\ B.S., University of Orleans (France), 2011 \\ M.A., University of Southern Mississippi, 2014
}

\begin{abstract}
A Dissertation
Submitted to the Faculty of the in Partial Fulfillment of the Requirements for the Degree of

Doctor of Philosophy in Criminal Justice

Department of Criminal Justice University of Louisville Louisville, Kentucky
\end{abstract} College of Arts and Sciences of the University of Louisville

May 2020 
Copyright 2020 by Caroline Isabelle Jalain

All rights reserved 



\section{GENDER-DIFFERENTIAL EFFECTS OF PERCEIVED DISCRIMINATION ON LAWYERS' JOB SATISFACTION: A GENERAL STRAIN THEORY APPROACH \\ By \\ Caroline Isabelle Jalain \\ B.S., University of Orleans (France), 2011 \\ M.A., University of Southern Mississippi, 2014 \\ A Dissertation Approved on}

March 31, 2020

By the following Dissertation Committee:

Dr. George E. Higgins, Dissertation Director

Dr. Viviana Andreescu

Dr. Elizabeth L. Grossi

Dr. Catherine D. Marcum 


\section{DEDICATION}

To the insecure $7^{\text {th }}$ grader who was told she would never be able to speak English, this dissertation is for you. You proved them all wrong. 


\section{ACKNOWLEGMENTS}

I would like to begin by thanking Dr. George Higgins. This journey would not have been possible without you. Who would have thought that after meeting you at ACJS you would become my dissertation chair, but more importantly, my mentor. You are who I want to be when I grow up and I will always hold you in the highest regard. Words cannot express how much I appreciate the countless hours of support, advice, encouragement, reassurance but also candid, sincere and practical advice you have offered me during the $\mathrm{PhD}$ program. You have inspired me to become a better student, a better teacher, a better scholar, and a colleague.

I would also like to thank Dr. Elizabeth Grossi. You took me under your wing on the first day and offered me opportunity after opportunity to grow as a student and a researcher. I am grateful for the guidance, resources and mentorship you have provided. Many thanks to Dr. Viviana Andreescu for spending hours reading my dissertation and giving me great feedback and suggestions to improve this document. I will miss our walks behind the SPI building and our long conversations about work but also life as a foreigner in the United States. I will forever cherish those moments. Thank you to Dr. Catherine Marcum for your support and encouragement during this process. You are such a positive and joyful person. I always look forward to seeing you at conferences or to chat on the phone or via email to get all of that positive energy from you. 
The PhD program at the University of Louisville has not only been a great academic experience but it also brought a wonderful person into my life. Emily Homer, we have done so much and have lived so many things together during these past three years. You have been my office mate, my classmate, my neighbor, my shopping partner, my workout partner, my conference partner, but more importantly, you have been my biggest cheerleader. Thank you for always being there to offer encouragement, support and for letting me vent my frustration when I needed it. Going through the PhD program would have been impossible without you.

Thank you to my American family (the Hulchers), and my Virginia friends for helping me have some fun while supporting me in this crazy adventure. Carrie Hulcher, Isaac Janak, Laura Kuthy and Alexis Jeffers, it has been a fun decade and I cannot wait to see what the next decade has in store for us. I would also like to thank my loving boyfriend Jake Hack who has supported me throughout this process. I am very grateful for your endless love and support, for being a shoulder to cry on, for sharing words of encouragement when I needed them, and for simply being there for me. The successful completion of this doctoral program would have been far more difficult without you. Lastly, I am eternally grateful for my parents who have been my rock and my biggest supporters since day one. You have instilled in me a strong sense of ambition, tenacity and curiosity which has made me the person I am today. I love you all! 


\section{ABSTRACT \\ GENDER-DIFFERENTIAL EFFECTS OF PERCEIVED DISCRIMINATION ON \\ LAWYERS' JOB SATISFACTION: A GENERAL STRAIN THEORY APPROACH \\ Caroline Isabelle Jalain}

March 31, 2020

The purpose of this study was to investigate the direct and indirect relationships between workplace discrimination and job satisfaction for lawyers. Using the After the $J D$ - Wave 1 data, a national longitudinal survey of law school graduates with a sample size of 4,538, and following a general strain theory approach, structural equation models were conducted to analyze gender-differential effects of perceived discrimination on lawyer's job satisfaction.

The results indicated that men and women lawyers differ in their experience with workplace discrimination and their job satisfaction. Notably, women lawyers were found to experience more instances of workplace discrimination compared to their male counterparts. Women lawyers were also more likely to be dissatisfied with their jobs compared to men. Lastly, women lawyers were more likely to experience workplace discrimination, which in turns, had a negative effect on their job satisfaction. 


\section{TABLE OF CONTENTS}

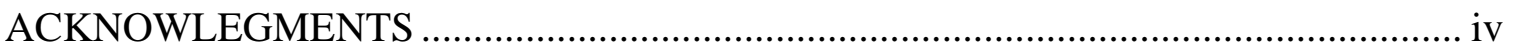

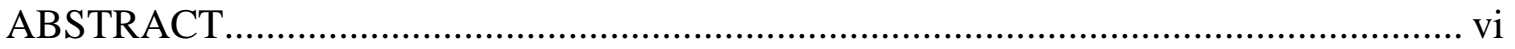

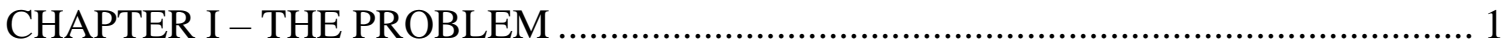

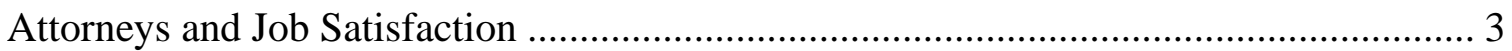

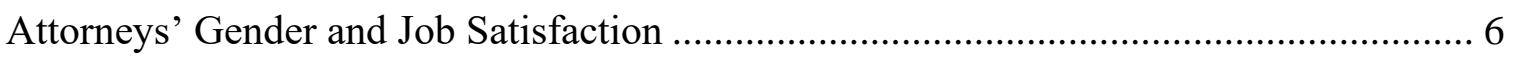

Attorneys and Workplace Discrimination .............................................................. 13

Gender and Workplace Discrimination ....................................................................... 17

Attorneys and Workplace Gender Discrimination............................................................. 21

CHAPTER II - THEORETICAL BACKGROUND .................................................. 26

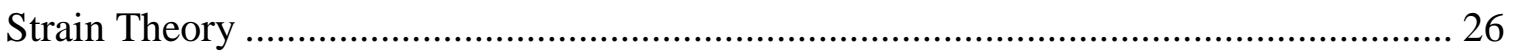

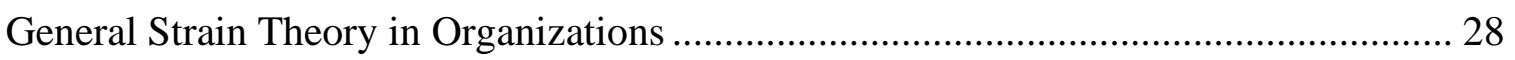

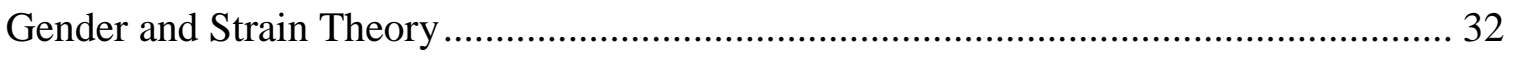

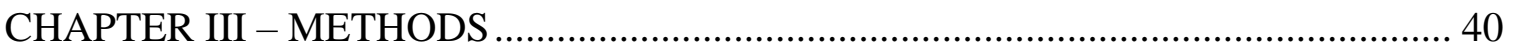

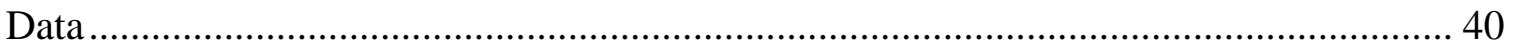

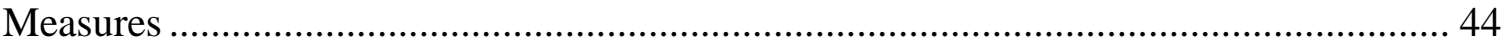

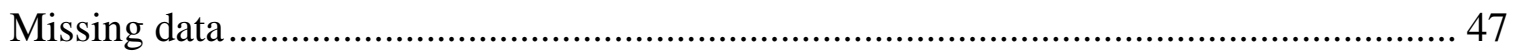

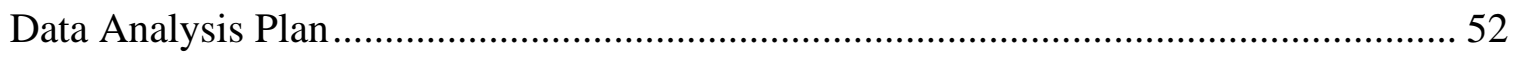

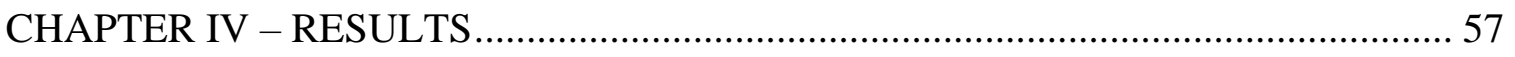

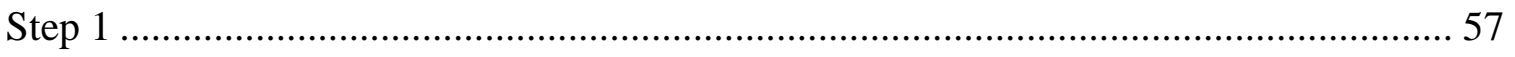

Step 2

Step 3

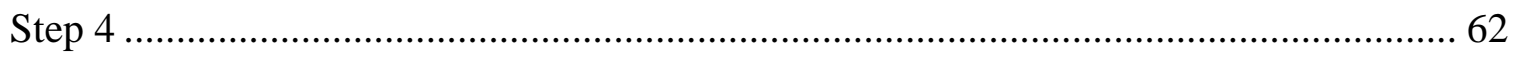

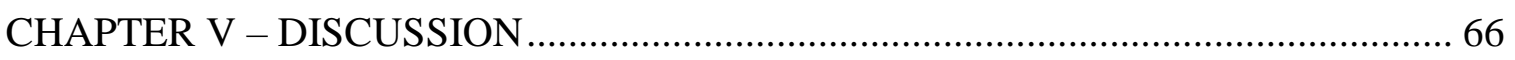

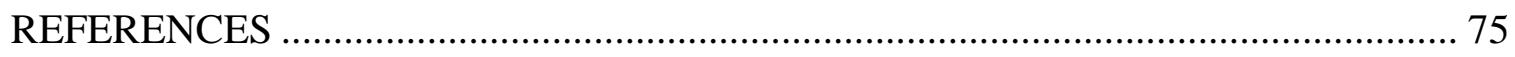

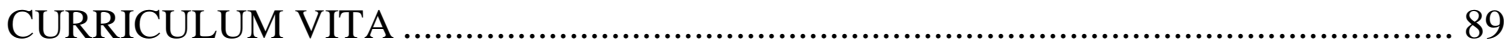




\section{LIST OF TABLES}

$\begin{array}{lll}\text { TABLE } & \text { PAGE }\end{array}$

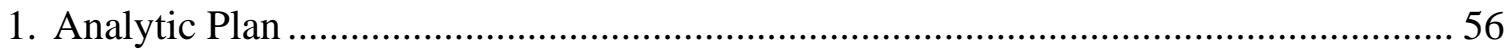

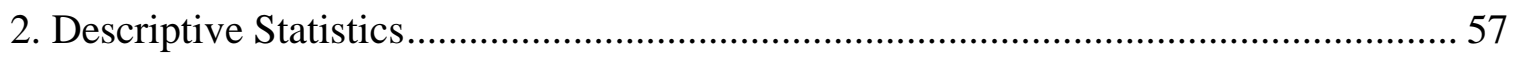

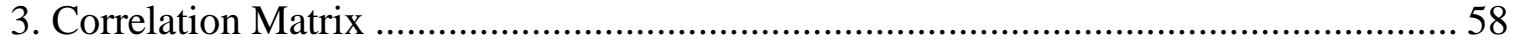

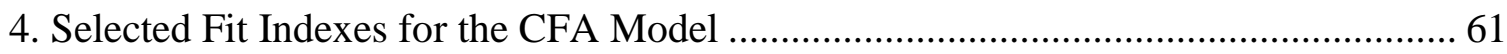




\section{LIST OF FIGURES}

$\begin{array}{ll}\text { FIGURE } & \text { PAGE }\end{array}$

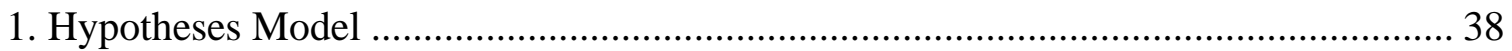

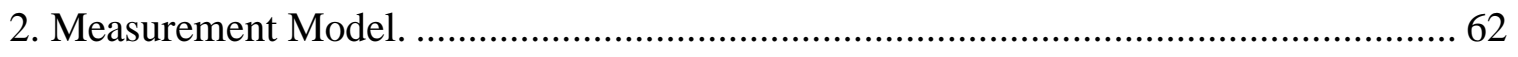

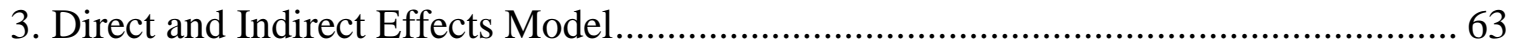

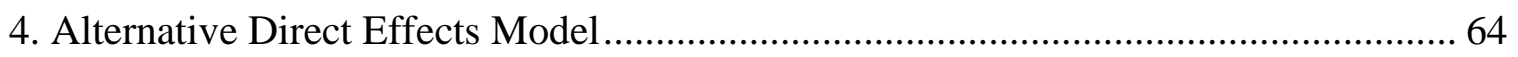

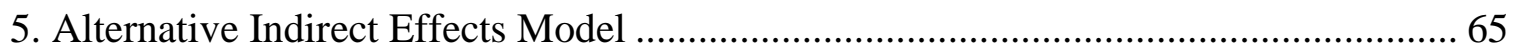




\section{CHAPTER I - THE PROBLEM}

In recent years, the disillusionment among lawyers became a subject of major concern. In their 2000 report, The New York City Bar Association's Task Force on Lawyers' Quality of Life assessed unhappiness among lawyers, especially young lawyers and measured its impact. The Task Force found that the repercussions of lawyers' unhappiness were significant as young lawyers who experienced decreased career opportunities were growing disillusioned and cynical. Consequently, those unhappy lawyers were not performing to their full potential, which negatively affected them, their firms, their clients, and their families and resulted in an increased turnover. This section discusses the "problem" of job satisfaction in the legal profession.

The phrase "quality of life" invites a closer look into the multidimensional concept that is life satisfaction. Life satisfaction is an evaluative judgement of the overall quality of an individual's life (Pavot \& Diener, 2008). The Satisfaction with Life Scale defines life satisfaction as satisfaction with work or school, family, friends, leisure, and personal development (Diener, Emmons, Larsen \& Griffin, 1985). When making life satisfaction judgements, Stubbe et al. (2005) found that one source of information pertinent to making life satisfaction judgements comes from levels of satisfaction with specific domain of someone's life such as marital satisfaction, satisfaction with housing, and job satisfaction (Pavot \& Diener, 2008). Thus, satisfaction possesses several 
definitions. For instance, in his book on social behavior, Homans (1961) defined satisfaction as a reward someone gets from doing an activity. Satisfaction, more specifically, job satisfaction can also be described as a positive attitude after one evaluates their job. Spector (1997) argued that studying the causes and the impact of employee attitudes has been at the center of organizational behavior and industrialorganizational psychology. He defined job satisfaction as an attitudinal variable referring to how much people like their job. All the different facets of the job are weighted and a total of influences from these facets will make someone satisfied or dissatisfied with their job. Smith, Kendall, and Hulin (1969) defined job satisfaction as "affective responses to facets of the situation" (p. 6). Concretely, individuals associate job satisfaction with what is fair to expect from a job and what is experienced while performing the job.

Furthermore, individuals have their own definitions of what job satisfaction is and what it means to them. Wolf (1970) reviewed the literature on the theoretical formulations of job satisfaction. He defined job satisfaction as a need gratification perspective that includes whether someone's job met their physical and psychological needs. Specifically, job satisfaction occurs when someone perceives that certain facets of their jobs help them achieve pre-determined goals. As Locke (1969) argued "Job satisfaction and dissatisfaction are a function of the perceived relationship between what one wants from one's job and what one perceives it as offering or entailing” (p. 316). Thus, when evaluating job satisfaction, one uses thinking and feeling about their job. In 
this dissertation, job satisfaction refers to an attitude, also understood as a positive or negative evaluation of someone's job.

\section{Attorneys and Job Satisfaction}

For the past three decades, increased attention has been paid to lawyers' dissatisfaction (Schiltz, 1999; Hull, 1999; Dinovitzer \& Garth, 2007). For instance, Delgado and Stefanic (2007) wrote "We reviewed the literature on lawyers' job satisfaction appearing in social science journals, law reviews, and bar journals. What emerged was not a pretty picture-what we termed "high paid misery." (p. 247). However, the literature on lawyers' satisfaction encompasses two drastically different views (Dinovitzer \& Garth, 2007). On one hand, literature has shown that the legal profession is "one of the most unhappy and unhealthy on the face of the earth" (Schiltz, 1999, p.872; Seligman, Verkuil \& Hang, 2001) while on the other hand, another body of literature found that lawyers are not as dissatisfied with their jobs as the literature suggests (Hull, 1999).

Nevertheless, since the 1980s there has been a reduction in the number of lawyers saying that they are very satisfied with their job (Gallup, 2017). With the heavy workloads for less pay, tediousness of the job, constant deadlines, workplace conflict, job insecurity, and a decrease in personal time, leading to job dissatisfaction, lawyers may experience depression (North Carolina Bar Association, 1991), stress (Heinz, Hull, \& Harter, 1999), burnout (Maslach \& Jackson, 1978), alcohol and substance abuse (Drogan, 1991; Benjamin, Darling, \& Sales, 1990), and suicide (Swain Daicoff, 2004). Job 
satisfaction for attorneys is linked to how their work aligns with their own personal values. Evans (2001) surveyed 700 Australian lawyers who had graduated between 1980 and 1998 to determine the values that were important to them in their profession. Evans (2001) found that women lawyers emphasized friendship/loyalty, personal integrity, and access to justice more, whereas men emphasized business efficacy, professional ambition and employer loyalty more. He defined job satisfaction for attorneys as providing them with creative challenges, important relationships and control over their working conditions.

On the other hand, Dinovitzer and Garth (2007) defined job satisfaction for lawyers as related to social background and the expectations and opportunities drawn from social hierarchies. As a result, job satisfaction is defined as a "mechanism" (Dinovitzer \& Garth, 2007, p. 1) combining social and professional hierarchies. Thus, job satisfaction for attorneys is perceived as a stratification mechanism through which attorneys achieve hierarchically arranged positions using their social class. Further, Kay and Hagan (2003) used a longitudinal survey of lawyers from Ontario, Canada who graduated between 1975 and 1990 to examine the important elements constituting job satisfaction. The authors found that satisfaction with intrinsic factors such as intellectual challenge and work, and extrinsic factors such as pay and benefits had an impact on lawyers' trust toward their colleagues, trust in their law firm, job satisfaction and retention. Kronman (1993) argued that observers of the legal profession noticed a growing obsession about making money. Further, Heinz and colleagues (1999) analyzed 
survey data from a random sample of lawyers practicing in Chicago gathered by the American Bar Foundation in 1994 and 1995. They found that lawyers' overall job satisfaction came from income levels. However, they argued that because job satisfaction was based on income, it did not mean that job satisfaction did not vary by race and gender. Because women and minority lawyers made a lot less money than white male lawyers, they were more likely to experience the effect of income level on job dissatisfaction.

Job satisfaction for lawyers can also be related to the length of time in practice or seniority. Lawyers who are recent graduates are less likely to be satisfied compared to people who have been practicing for years. Wasby and Daly (1994) surveyed 396 lawyers within multigenerational families and conducted 22 interviews with lawyers in New York and Boston. Results showed that the more experienced attorneys were more satisfied with their jobs compared to the less experienced attorneys. lawyers in private practice are less likely to be satisfied with their job compared to people who practice in the public interest or those who work for the government. Indeed, the American Bar Association Young Lawyers Division (1991) published its 1990 survey in which it showed that lawyers' satisfaction had decreased from $81 \%$ in 1984 to $76 \%$ in 1990. Specifically, even though they were paid less, government attorneys and attorneys doing public interest work were more satisfied than corporate and private practice attorneys. Private practice attorneys were more likely to exhibit higher levels of stress, especially if the firm was small. 
Lawyers in corporations were more likely to have a higher pay, but less control over their work.

Furthermore, stress coming from debt can contribute to lawyers' job dissatisfaction. Many lawyers graduate law school with six figure student loans. This causes stress and can have an impact on everyday job satisfaction. Fuchs Epstein, Sauté, Oglensky and Gever (1995) argued that many young lawyers graduated law school believing that they could work in firms so large and successful that they can pay off their loans, get training for a few years and then work for firms they really wanted to work for. Regrettably, in his review of the literature on law students' loans repayment, Schrag (2000) demonstrated that, when making the decision to pay off debts, law school graduates have to balance the "psychological stress of being in debt against the value of having more money to invest” (p. 820). As a result, the appeal of earning a high salary and having a gracious lifestyle makes it difficult for these lawyers to leave the corporate world. All in all, factors that increase job satisfaction for lawyers are autonomy or control over work, relatedness to others in the firm, feeling competent while performing their legal job, internal motivation such as finding the job meaningful, and enjoyable, personal growth, feeling like you are helping others through your job. However, these factors do not affect men and women lawyers equally.

\section{Attorneys' Gender and Job Satisfaction}

This section explores the relationship between lawyers' gender and their job satisfaction. Teitelbaum, Lopez and Jenkins (1991) surveyed alumni from the University 
of New Mexico Law School who had graduated between 1975 and 1986. They found that women respondents chose a legal career later in life compared to men. Almost $60 \%$ of male respondents enrolled in law school after graduating college compared to $41 \%$ for women. Women were also three times more likely than men to have entered law school after a gap of over ten years and twice more likely to have entered law school after a gap of five or more years compared to men. Regarding reasons for attending law school, no gender-differences were identified. Men and women also reported similar experiences during their years spent in law school. Additionally, both men and women reported similar perceptions of the competitive aspects of the profession and its associated stress. Additionally, there was no gender-differences in satisfaction with relations with judges and other lawyers. However, women saw cooperation with colleagues as more important for their job satisfaction than men did. Finally, women did not report having experienced higher stress levels because of having children.

Regrettably, literature on women of color entering the legal profession is sparse. However, Norgren's (2008) lecture at the Association of the Bar of the City of New York provided evidence of the intellectual process of first-generation American women lawyers who fought against a patriarchal society and advocated for women to be able to go to law school and become lawyers. This unique lecture examining first-generation lawyers and the impact of workplace discrimination on their job satisfaction was the first account of research on women of color in the legal profession. With more and more women becoming lawyers, the legal profession had to assimilate women. However, 
Schultz and Shaw (2003) argued that while law professions have assimilated women, some aspects of the job have not accommodated the fact that women may have different needs when it comes to feeling satisfied with their legal job compared to men. If those needs are not met, women are more likely to quit their job or underperform as a consequence of lower job satisfaction.

Wallace (1999) surveyed 512 lawyers in a metropolitan city in Canada. He examined work-to-non-work conflict for male and female lawyers. Work-to-non-work conflict was described as work invading one's family life and has two components. The first component was time-based conflict where the time associated with work invaded the time associated with another role, in this case, family life. The second component was strain-based conflict where someone was preoccupied with one role while trying to do the other role. In this case, one's work preoccupations after having left work was causing strains that could affect the physical and psychological needs that should exist for the non-work role. Wallace (1999) found that work overload had a significant effect on work-to-non-work conflict for both male and female lawyers. Work context had a stronger impact on women's work-to-non-work conflict. Working longer hours, working in a place with a lot of women colleagues, and having a wife that was an income producer led men to exhibit higher time-based conflicts. However, working longer hours did not always lead to work-to-non-work conflict as lawyers had the flexibility to schedule their own worktime. Surprisingly, results showed that the domestic status of female lawyers did not have an impact on their time-based conflicts. The author argued that this may be 
due to the fact that women had found a way to balance a demanding career and their family lives, as the career allowed them to pay for childcare and domestic help.

Other authors found that women were less satisfied about their work hours and their work schedule compared to men to the point where some women reported planning to look for a job in the next year or leaving the legal profession altogether because of job dissatisfaction. For instance, Reichman and Sterling (2002) interviewed lawyers in Colorado. They reported that women lawyers were more likely to make the decision to leave their job because of poor work assignments, lack of recognition for their work abilities, and issues findings a mentor. The authors argued that sometimes the decision to leave was based on a push away from work but sometimes could be based on a pull of the family.

When assessing job satisfaction among lawyers based on gender, research reports conflicting results. Some say that even though women lawyers are less satisfied with their job in regard to opportunities for advancement, and job setting, overall both men and women lawyers tend to be satisfied with their job. Heinz et al. (1999) found high levels of satisfaction for all categories of attorneys. This suggests that lawyers may not differ greatly from other labor forces in their attitudes toward their job. Others found that women lawyers are more satisfied with the substance of their work compared to men (Dinovitzer, Garth, Sander, Sterling, \& Wilder, 2004). However, it has been found that women are more likely than men to say that, if given a choice, they would not pick lawyer as a career again. 
Heinz and colleagues (1999) surveyed 788 lawyers who worked in Chicago to determine their job satisfaction. They did not find any gender differences in overall satisfaction. Interestingly, even though $84 \%$ of surveyed lawyers reported being satisfied or very satisfied, only $77 \%$ of respondents said they would choose to become a lawyer again, if given the possibility to do something else. Specifically, $79 \%$ of male lawyers said they would choose to be a lawyer again compared to $71 \%$ for female lawyers. Women lawyers, especially those who had a job in a private practice, reported being less satisfied with their job. Biddle, and Hamermesh (1998) used longitudinal data from people who had graduated one law school and were shown pictures to measure beauty. The premise was that earning differences among workers is based on specific group characteristics. Therefore, respondents were asked to look at differences in salary based on differences in physical attractiveness. The authors reported that better looking attorneys who had graduated in the 1970s had higher salaries after years of practice. They also found that lawyers in the private sector were perceived as better looking compared to lawyers who worked in the public sector.

Additionally, women have been found to be the most satisfied in mid-size to bigger firms compared to men who are more satisfied when working in a smaller firm. Beiner's (2008) study reviewed the literature on women lawyers in big firms and the different components that made women less satisfied with their job and leave their job earlier than men. Being a working mom and spouse had an impact on their satisfaction. It was usually positive, but the author argued that female lawyers were more likely to be 
single and childless compared to men. When they were married and had children, women lawyers were more likely to be satisfied with their job. This is consistent with Chambers' (1989) study. Chambers (1989) analyzed data from late 1970's graduates from the University of Michigan Law School and found no evidence of a gender difference in job satisfaction. However, he concluded that women who had children reported higher rates of job satisfaction.

Further, Dinovitzer and Garth (2007) used the first wave of the After the JD study to assess gender differences in job satisfaction for lawyers. They found that attorneys' social background, understood as the ranking of the law school they went to, had an impact on job satisfaction. They analyzed job satisfaction using the obstacles and rewards that attorneys experience in their job. Dinovitzer and Garth (2007) reported that respondents who went to one of the 10 most prestigious law schools in the country reported working with clients in corporations $69 \%$ of their time compared to $35 \%$ for individuals or small businesses. Results showed that as we go down the hierarchy of law schools, the relationship reverses. Finally, job satisfaction among female lawyers was significantly lower when female lawyers had witnessed or experienced sexual harassment by male colleagues or male superiors.

Work dissatisfaction among female lawyers are sometimes tied to the idea that the highest positions in law firms are not filled with as many women as there are in the lawyer population. Indeed, women make up for one third of the legal profession in North America (Gallup, 2017). However, they only make up a small percentage of partners and 
managing partners. Rhode's (2001) report provided a review of the literature on women in the legal profession. She argued that women in the legal profession were underrepresented in position of power. Women only represented $15 \%$ of federal judges and partners in their law firms, $10 \%$ of law school deans and general counsel and $5 \%$ of managing partners in larger firms. Women were also found to being paid less than their male counterparts (about $\$ 20,000$ less). The report also highlighted that only $3 \%$ of lawyers are women of color. Since the early 2000s, there has been a significant change in gender representation in the legal profession. In 2019, there are 124 women judges on state courts of last resort, representing $36 \%$ of the total number of state judges of last resort. 39\% of intermediate appellate judges are women, 33\% of courts of general jurisdiction judges are women, and $36 \%$ of judges in courts of limited jurisdiction are women (National Association of Women Judges, 2019). At the federal level, 33\% of United States district court judges are women, $36 \%$ of federal courts of appeal judges are women and three supreme Court Justices are women (National Women's Law Center, 2016).

Dinovitzer and Garth (2007) argued that differences in job satisfaction are signs of discrimination and inequality in the job. Therefore, in addition to the sex-based inequalities of pay, promotion and career advancement, one factor that is also contributing to women's job dissatisfaction is their experience with discrimination in the form of sexist treatment. Hagan and Kay (2007) used a panel study of lawyers who had been practicing in Toronto since the mid 1980's to look at the impact of gender on job 
dissatisfaction. They reported that gender differences in occupational power had an indirect effect on job satisfaction. The authors also found that perceived powerlessness directly impacted job satisfaction and that feelings of despair caused by the concerns of potential consequences of having a family, especially children, had an effect on job satisfaction. Finally, the authors found that women were more likely to respond internally to these work strains and not publicize their feelings of job dissatisfaction. Overall, research on discrimination and job satisfaction has shown that it is a reality, even among lawyers. The purpose of this dissertation is to examine the direct and indirect relationships between gender and first-generation lawyers, workplace discrimination and how these relationships affect job satisfaction.

\section{Attorneys and Workplace Discrimination}

This section discusses attorneys' experience with workplace discrimination. Discrimination is defined as treating someone negatively based on a protected personal characteristic. Several types of discrimination can occur in the workplace. Reskin (2000) defined workplace discrimination as self-interested acts performed by privileged members of society in order to protect their own interests. Thus, since lawyers' place of work may vary between public or private sector for example, it is expected to find differences when instances of discrimination occur. Collins, Dumas and Moyer (2017) defined workplace discrimination as one's perceived unequal treatment by other attorneys in the workplace. The authors used a survey of over 2,000 attorneys to assess the impact of race, gender, and age on attorneys' perceptions of discriminatory treatment by other 
lawyers and on satisfaction with their job. They found that minority women attorneys were more likely to perceive discriminatory treatment based on race, gender and age. Additionally, workplace discrimination for minority female attorneys was found to contribute to lower job satisfaction.

Attorneys feel discriminated against when they are asked to produce documents and perform legal research duties instead of doing trial work or depositions. This may be based on race, gender, age, or experience. Specifically, men and women of color are often discriminated against when they are not given desirable assignments such as the way client-service assignments are distributed or getting access to working on highprofile client engagements and are denied informal and formal networking opportunities because of race (Bagati, 2009). Moreover, people of color, especially Black attorneys are also victims of workplace discrimination. Woodson (2016) interviewed 75 Black attorneys who worked as associates at major law firms in the Unites States. He found that one third of the respondents reported having received less access to advancing work assignments, opportunities for career development and mentorship opportunities when compared to White associates in their firms. However, Woodson (2016, pp. 184-185) argued, because empirical studies on this topic are lacking, we can only speculate that these factors could explain minority lawyers' perceived discrimination. Woodson's study contributed to filling the existing gap in the literature. He interviewed 75 Black attorneys who worked as associates at major, predominantly white, law firms in the United States. Woodson found what he called "human capital discrimination" (p. 185), understood as 
instances of mistreatment that deprived Black attorneys from advancing their careers. Black attorneys were less likely to receive high quality opportunities that would help develop their careers. Finally, Woodson (2016) reported that human capital discrimination and its negative effects were not covered by Title VII (i.e. prohibition of employment discrimination based on race, color, religion, sex and national origin). Furthermore, men and women of color have also been missing client development or relationship opportunities because of race. The same is true for opportunities for advancement and promotion.

Additionally, Jex and Beehr (1991) and Spector (1997) described workplace discrimination as being a job strain that will ultimately increase job stress and job dissatisfaction. Ragins and Cornwell (2001) reported that perceived discrimination in the workplace was related to negative work attitudes and less possibilities for career advancement. Workplace discrimination can have a detrimental impact on employees' overall job satisfaction, as their health and emotional well-being may be impaired. Arshadi and Damiri (2013) surveyed 286 employees who worked at the Iranian National Drilling Company. They found a negative relationship between job stress and job performance and a positive relationship between job stress and intentions to leave their job. They also discussed "organization-based self-esteem" (p. 707) which was defined as the perception of a worker's own capacity to do the job and his/her worthiness. Arshadi and Damiri (2013) found that organization-based self-esteem had a moderating effect on the links between job stress, intentions to leave job and job performance. 
Rhode (2011) argued that while the Bar is committed to equal opportunities and fairness, this is not the case in practice. The reason is that there is a lack of consensus to determine what makes a law firm discriminatory based on gender, race and age. In the legal profession, white males are dominant at all levels. Rhode (2011) found that discrimination against Black and Latino lawyers takes the form of biases. Even though they may have graduated from a prestigious law school, Black and Latin lawyers are perceived as less intelligent, less qualified and that they got to where they are based on affirmative actions and not merit. Discrimination against Asian American is based on the idea that this segment of the population is smart but not assertive enough for clients and legal team members to be confident in their abilities to perform their job. In addition, Rhode (2011) explained that Black attorneys reported having been mistakenly confused with criminal defendants and court personnel.

When opportunities are not being offered to lawyers, it seems probable that they would want to leave the firm and work at a place where they would be appreciated and treated fairly. Williams, Bornstein, Reddy and Williams (2007) analyzed the literature on law firms as defendants and discrimination in legal workplaces. The authors found that since 1990, 33 cases were filed by employees of law firms where they have sued their employers for family responsibilities discrimination. Family responsibilities discrimination refers to discrimination based on employees' family caregiving responsibilities for people such as newborns, young children, elderly parents or ill spouse or ill partners (Center for Work Life Law, 2006). Because of the structure and culture 
within law firms, family responsibilities discrimination led lawyers to feel like they were missing out on opportunities for advancement which in severe cases prompted litigation, lawsuits and the employee leaving the firm. Regrettably, few research exist on the topic. According to Collins et al. (2017) "there is no existing systematic study that takes an "intersectional" approach to understand how attorneys experience discrimination by their professional peers" (p. 1643). In other words, before their study, nobody ever looked at the intersection of age, race and gender discrimination for attorneys.

Gender and Workplace Discrimination

Workplace gender discrimination involves different treatments that have a negative impact on someone's employment based on their gender. Rhode (1988) defined workplace gender discrimination as assumptions that women cannot perform certain jobs because of their intellectual, physical and psychological incapability. Unlawful workplace gender discrimination occurs when an employer treats a potential employee or a hired employee differently and less favorably because of his or her gender or because the person belongs to a group that is affiliated with a particular gender that does not fit the traditional notions of femininity or masculinity. Workplace gender discrimination is also defined as unwelcome sexual advances, verbal, physical, or sexual harassment, offensive remarks from someone from one gender (most times male) to a person from the opposite gender (most times female) (Benya, Widnall, \& Johnson, 2018).

The United States Equal Employment Opportunity Commission (2011) defined sexual harassment as "unwelcome sexual advances, requests for sexual favors, and other 
verbal or physical conduct of a sexual nature" that interferes with one's employment or work performance or creates a "hostile or offensive work environment". Moreover, McLaughlin, Uggen and Blackstone (2012) found that sexual harassment can be defined as a weapon against women in power by someone who is motivated by gaining control and dominating, rather than sexual desires. The authors used longitudinal survey data and qualitative interviews from 522 participants in the Youth Department Study. Results revealed an interaction between gender and power in the prediction of sexual harassment. Indeed, female supervisors were found to be more likely to report sexual harassment. Specifically, women who had higher supervisory authority, as they were supervising a large number of people, were more likely to report sexual harassment. Particularly in male-dominated settings, women in position of power reported social isolation as a link to sexual harassment. Antecol, Barcus, and Cobb-Clark (2009) reported that both sex discrimination and sexual harassment are associated with high rates of job dissatisfaction.

Women have been found to face gender discrimination in the workplace as they generally perform lower level jobs, are paid less, have a lower status in a company, have lower authority levels and lower advancement prospects across a wide array of occupations compared to men. Rhode (1988) presented information about the historical movement for women's acceptance in male-dominated professions. The author provided a lengthy argument about gender-related problems in professional settings, specifically, occupational inequalities. Historically, women were seen as being a part of the private sphere where they could not act independently, hold a job, own a house or enter 
contracts. This caused women to receive little financial and emotional support for their job aspirations. Women who tried to go against stereotypes and managed to have both a career and a family would face criticisms.

In the 1920's, women were facing less formal gender-segregation, however, informal segregation remained. This led to women still being underrepresented in position of power and influence. In the late 1960's, a growing number of demands for female-dominated jobs encouraged more women to look for paid job opportunities. However, qualified women may not get a promotion because people in the position of power in the company found out they were pregnant. As a result, jobs or promotions may be offered to less qualified men, simply because they are men. Rhode (1988) argued that gender differences in the workplace can take the form of arguments such as: a woman's contributions to a job based on her own qualities are more essential in a domestic setting than in a work setting. Women are more likely to be judged on the way they look, or how they dress compared to men. In jobs involving sales or public relations, women are sometimes discriminated against because they are considered too pretty, or too provocative. However, they can also be discriminated against for being not pretty enough or too old. Acker (1990) argued for a theory of gendered organizations. Her article described how organizational practices have furthered gender segregation of work and pay. She examined gender and sexuality in the work place and found that gender, sexuality and body image were part of processes of control in organizations. For instance, equal opportunity recruitment in organizations did not mean no discrimination. 
Even though there are protective anti-discrimination laws in place, small, mid-size and big organizations often push for the advancement of men over women. Moreover, women are often the subject of subtle discrimination by both sexes in the workplace. Bobbitt-Zeher (2011) analyzed 219 sex discrimination cases narratives brought to the Ohio Civil Rights Commission to determine how gender stereotyping and institutional policies affected gender discrimination. The author reported that workplace policy application and enforcement were responsible for how gender-based assumptions were translated into unequal treatment of women in the workplace. Indeed, people in position of power used policies in a selective manner that disadvantaged women. This policy discretion created gender discrimination in the workplace. Gender stereotypes also created gender discrimination in the workplace. In male-dominated workplaces, men were likely to view women as invaders, leading to gender stereotyping and higher gender expectations. However, in a female-dominated workplace, stereotyping also occurred as women may be considered inferior to men or may be criticized if they do not do "gender" (p. 782) properly. Further, Rhode (1988) argued that gender bias for women in a maledominated job caused women to have issues with "fitting in" (p. 1190) as they had a harder time to form bonds with colleagues and clients. Those bonds were necessary for career advancement. As a result of workplace gender discrimination, women were likely to feel pressured to compromise their personal or professional life in order to fit in maledominated jobs. Alternatively, women may be more likely to gain authority and challenge existing sexist structures and values in their job. 
Workplace discrimination also has an impact on employees' general wellbeing. Schneider, Swan and Fitzgerald (1997) found that women who reported incidents of sexual harassments, such as sexist jokes or inappropriate touching, in the workplace were likely to exhibit negative psychological effects as a result of such harassment. Moreover, Swim, Hyers, Cohen and Ferguson (2001) described how exposure to everyday sexist incidents was associated with increased anger, depression and decreased self-esteem for women. Gender discrimination can also cause someone to have increased psychological and physiological stress levels (Miller \& Kaiser, 2001). As being the target of everyday discriminatory incidents negatively impacts several aspects of individuals' well-being such as job satisfaction, emotional and physical well-being (Deitch et al., 2003; Taylor, McLoughlin, Meyer, \& Brooke, 2013), it is important to asses workplace discrimination for lawyers, specifically, workplace gender discrimination.

\section{Attorneys and Workplace Gender Discrimination}

This section discusses attorneys' experience with workplace discrimination based on gender. Work satisfaction among lawyers has been defined by the assumption that differences in satisfaction are signs of discrimination or inequality in the organization. Morello (1986) defined workplace discrimination for women attorney as men's perception of women's incapacity to treat the law in a professional fashion. Gender discrimination as attorney revolves around the idea that women's opportunities are limited because of traditional gender stereotypes. Spurr (1990) studied the promotion experience for female lawyers to determine if there were differences. The author 
combined two data sets from the Martindale-Hubbell Law Directory. 2,116 lawyers who entered 139 different law firms from 1969 through 1973 and 293 lawyers who entered the 17 biggest law firms in New York City and Chicago in 1980 were surveyed. The author demonstrated that women entering the legal profession increased from 3\% in 1968 to $33 \%$ in 1983. Results also showed a difference in men and women's prospects for promotion. Even if they did not differ in their selection for law review, rank of their law schools or productivity, women were found half as likely as men to be considered for promotion as partner. Furthermore, women victims of workplace gender discrimination as an attorney likely face inadequate access to mentorship, lack of informal networks of support, and/or inflexible workplace structure. Reichman and Sterling (2002) described that men and women reported being treated differently by male colleagues. Specifically, they found that women were more likely to be denied assignments with important clients or important cases. These instances prevented women from obtaining opportunities for advancement because of their gender.

While women were told for years to comply with men's rules and minimize issues at work, with the development of women empowering movements, careerist women broke those norms to better their work experience. In a workplace that does not put in place policies to moderate the general climate within the organization, increasing numbers of women in the legal profession might be perceived as threatening for some men who use workplace discrimination as a way to protect the boundaries of their domain. As a result, men may default back to strategies of workplace discrimination such 
as preventing women from certain work opportunities, not informing them about an important event or meeting, or stealing their clients and more extremely, sexual harassment.

Kay and Gorman (2008) reviewed the literature on women in the legal profession and found that even though women are now exceeding parity with men in many law schools, gender discriminations still remain. Gender differences were visible in regard to career mobility, specifically being promoted to partner and the following hiring or job moves, along with pay gaps between male and female lawyers. They found that women were still confronted with double standards and gender stereotypes which prevented them from job opportunities. Nonetheless, the literature shows that instances of discrimination such as sexual harassment is on the decline but has not completely disappeared. Gender differences in discriminating and sexist behavior has been attributed to an organization in which the culture places importance in attributes or traits that belong to men. In this type of organization, discrimination and harassment are more likely to occur.

In regard to sexual harassment in the legal profession, using data from the American Bar Association's, Laband and Lentz (1998) studied 744 lawyers employed by the government, corporations and private practice. They found that approximately two third of female respondents in private practice and almost 50 percent of female lawyers working in corporate firms and government agencies reported having experienced or observed one or more types of sexual harassment. Sexual harassment instances that were reported occurred between a female lawyer and a male supervisor, a colleague or a client 
during the two years before the survey was administered. Female respondents who had experienced or witnessed such harassment reported lower overall job satisfaction and a stronger intention to leave their job.

Studying differences in workplace discrimination for women lawyers is important for several reasons. Firstly, the hiring of a growing number of female lawyers should indicate a move toward creating a more inclusive and equal work environment in the legal profession. However, since the late 1980's and 1990's, equal opportunity recruitment has yet to mean no discrimination during the hiring process. Especially among young lawyers, women are more likely to leave large firms disproportionately compared to men. Because of stereotyping of their roles and negative expectations and traits, women lack encouragement within the firm to advance their career when their start having a family. This can result in the diminution of business being given to them or diminished assistance when developing a client base (Fuchs et al.'s, 1995). When women's opportunities are limited because of traditional gender stereotypes, women lawyers are more likely to make less money, less likely to become partners, and have less opportunities for advancement compared to their male counterparts. As a result, they may be more likely to leave their job sooner.

Hodgson and Pryor (1984) analyzed perceptions of attorney’s credibility and verdict in court cases based on their gender. They used 84 men and 84 women enrolled in speech classes at the University of Central Florida. The treatment group read a summary of a mock case and the audiotape of the closing arguments of a male and female defense 
attorney. The control group read the arguments but did not listen to the audiotape. All participants completed a post-test evaluation of the attorney and the verdict for the mock trial. They found that women rated female attorneys lower on a credibility scale and found female attorneys less trained compared to male attorneys. They did not find significant differences in credibility for male respondents. They also found that the female lawyers' clients received a higher number of guilty verdicts compared to male attorneys. However, respondents based their judgement of guilt or innocence on the evidence and not on the attorney's credibility. Finally, when asked which male or female attorney they would retain for themselves, respondents said they would retain the male attorney more often than the female attorney. As workplace discrimination can be considered a strain, the following section describes strain theory and how it applies to job dissatisfaction among lawyers. 


\section{CHAPTER II - THEORETICAL BACKGROUND}

\section{Strain Theory}

This chapter highlights the importance of using Strain Theory as the theoretical framework to assess the role of workplace discrimination on job satisfaction for lawyers. The perception that one is victim of workplace discrimination may have important negative implications. To date, no research has explicitly assessed the impact of attorneys' workplace discrimination on job satisfaction. To better understand the link between workplace discrimination and negative emotions, it is helpful to understand workplace discrimination as a stressor or a strain. Strain theory sees humans as rational and performing a hedonistic calculation before making decisions. Walters (2015) reviewed the literature on the role of emotions in the process of criminal decisionmaking. He found that individuals exhibit hedonistic and moral emotions when making decisions. The hedonistic emotional aspect will provide an individual with the benefits he or she will get from a certain action. In addition, the moral emotional aspect will provide information about potential costs.

Strain theory is also defined in terms of negative relationships with others where an individual is not treated the way he or she would like to be treated (Agnew, 1992). Strain theory initially focused on relationships that are preventing someone from achieving positively goals. Agnew (1992) distinguished strain theory from social control 
and social learning theory, then described each type of strain, how to measure strain and the adaptations to strain. Contrary to classical strain theory which only focused on one relationship (Agnew, 1992), Agnew (2001) extended the theory to include relationships in which individuals are presented with negative stimuli. Thus, strain can be the result of three types of negative relationships: when others: prevent or threaten to prevent the achievement of positively valued goals, remove or threaten to remove positively valued stimuli, or present or threaten to present negatively valued stimuli (Agnew, 1992).

The first concept of strain theory is to prevent or threaten to prevent the achievement of positively valued goals. (Agnew, 1992). The strain of failure to achieve positively valued goals possesses three components. The first component is how individuals perceive the difference between their aspirations and their achievements. This can be influenced by their social class, their education level, their physical ability, even sometimes their physical appearance. The second component is the difference between expectations and achievements. Expectations are created when individuals have ideal goals that are drawn from the understanding of what the person should be able to achieve. The last component is the difference between outcomes that are perceived as fair and just and the actual outcome. This is influenced by someone's perception of fairness (Agnew, 1992; Eitle, 2002).

Strains can cause emotional responses. The most common responses are anger, frustration and other negative emotions (De Coster \& Zito, 2010). These emotional 
responses are a preparation for coping. General strain theory (GST) argued that once strains have reached a certain level, someone is more likely to cope with it by exhibiting delinquent behavior. To that extent, Agnew's (1992) article provided a more complete explanation of all the emotional and cognitive adaptations one experiences when in presence of strains. Additionally, since people differ in how they subjectively evaluate a situation, there is a distinction to make between two types of strains. Strains can be objective (i.e. disliked by most members of a specific group) or subjective (i.e. disliked by people who are experiencing them). One form of coping is crime and deviance. However, it is difficult to know which strains are more likely to trigger crime because the emotional response is subjective, it is based on the individual. Thus, according to Agnew (1992), most people do not use delinquency as a coping mechanism and use other nondelinquent coping skills instead.

\section{General Strain Theory in Organizations}

Organizational structures often govern relationships between employees and their organizations, and many of these relationships are stressful. Warr and Payne (1983) surveyed working individuals in Britain and asked if they had experienced having been upset because of work the day prior to the interview. About $15 \%$ of male respondents and $10 \%$ of female respondents answered positively. Additionally, strain can be externally exhibited as stress. Johnson et al. (2005) studied occupational stress across 26 different occupations. They used a stress evaluation tool to assess three stress variables (psychological well-being, physical health and job satisfaction). They found that 
respondents who had high stress levels were also reporting low levels of job satisfaction. Cooper and Cartwright (1994) presented a review of empirical studies on issues that impact employees' well-being, health and their organization. They found that occupational stress will continue to be a problem in organization from both a financial health aspect and profitability aspect. The authors argued that rather than focusing on what the organization can do to help employees cope with stress, organization should implement strategies to eliminate or reduce workplace stressors.

Agnew's (1992) GST is the only major criminological theory that focuses on negative relationships between people and their environment. By focusing on negative relationships, GST provides an important framework to assess the negative affective response from different work stressors. For instance, Piquero (2005) studied the negative responses stemming from stressors related to the policing profession. Additionally, GST has been used to assess the influence of occupational strain on organizational commitment among police (Moon \& Johnson, 2012). Moon and Johnson (2012) examined the effect of all three strains defined by Agnew on organizational commitment of 180 police officers. They found that GST was a viable framework to study police officers' direct responses to strain. Moreover, the authors examined the relationship between subjective strains such as experiencing a traumatic or dangerous event and alcohol abuse by police officers. They found that anxiety and depression, rather than anger were mediators in the strain/alcohol abuse relationship. Lastly, Bishop, Piquero, N. L., Worrall, and Piquero A. R. (2018) used GST at their theoretical framework to study 
the main sources of police strain as predictors of anger, depression and burnout in three urban Texas police agencies. Results showed that organizational stress predicted each of the negative affective responses and that the relationship between organizational stress on negative emotions was always significant. Thus, organizational stress was problematic for police officers in all three locations and for all three negative emotions that the authors examined. As GST has not been used solely to explain crime and deviant behavior but has been used to explain organizational strain, Agnew's (1992) GST provides a useful theoretical framework within which the relationship between lawyers' strain, negative emotions and job dissatisfaction can be investigated.

Agnew $(1992 ; 2001)$ argued that certain events in someone's life can cause them to experience negative emotions. Thus, those negative emotions are experienced through the introduction of noxious stimuli (Agnew, 2001) and the evaluation that such stimuli are a threat or are harmful (Agnew, 2001). Agnew (1992) described events such as a treatment of disrespect as a stressor. Thus, workplace discrimination can be seen as a disrespectful treatment. Moreover, research shows that there is a link between discriminatory practices and negative emotions (Baron, 2004; Eitle, 2002; Eitle \& Turner, 2003; Higgins \& Gabbidon, 2009; Preston, 2006; walls, Chapple, \& Johnson, 2007). Therefore, negative emotions generated with workplace discrimination can lead to job dissatisfaction. Employees experiencing workplace discrimination occurs in many occupations. 
When someone is prevented from achieving something that is important to them, they are deprived from an opportunity to do something that would make them feel good. As it relates to the work environment, when an employee is prevented from achieving a positively valued goal, the person may think that he or she is not contributing to the company or may not feel fulfilled by their job since they cannot achieve their goal. (Broidy \& Agnew, 1997; Eitle, 2002). The literature says that each sub-concept of this strain is relative to a type of relationship with others (Eitle, 2002). Thus, finding the source of that strain will help someone finally achieve their positively valued goal, whatever the goal is.

In Agnew's (1992) view, a second source of strain is the removal or threat of removing positively valued stimuli. The literature uses examples such as losing a friend, ending a relationship or being fired from a job to explain the removal of a positively valued stimuli (Broidy \& Agnew, 1997). When a positively valued stimuli is removed from an individual in the workplace, one result can be delinquency. Vengeful behavior in the workplace can have detrimental effects to the work environment, relationships with colleagues and fulfillment of work duties. (Eitle, 2002)

The third concept of strain theory is to present or threaten to present negatively valued stimuli (Agnew, 1992). This last strain is based on the idea that an actual or expected negative stimuli will be introduced into someone's life. (Agnew, 1992; Eitle, 2002). The presentation of negative stimuli is likely to cause people to respond aggressively to the situation. For instance, when juveniles are presented with negative 
stimuli, they are more likely to engage in delinquency as a way to avoid or escape from that stimuli. Delinquency can also be used as a way to seek revenge against the stimuli (Eitle, 2002). Examples in the literature for this third strain are physical, psychological, or sexual abuse, domestic violence, child neglect, dangerous school environment (Broidy $\&$ Agnew, 1997). Toxic work environments would likely fall under this category. Recent research reported that exposure to stimuli from toxic people caused subjects' brains to have a massive stress response (Walsh, 2017). Regrettably, the legal profession is not exempt from it (Dowell \& Fortgang, 2019). Therefore, it is important for GST to focus on a pivotal component of GST that is the direct relationship between straining events and negative emotions. Similar to Moon and Jonson (2012) who measured the presentation of noxious stimuli via stressful encounters and work/role responsibilities to explain police officers' organizational commitment to their agencies, this dissertation measures the presentation of negative stimuli via workplace discrimination to explain lawyers' dissatisfaction with their job (i.e. negative emotion).

\section{Gender and Strain Theory}

Considering the arguments presented in regard to GST, since women are in general more distressed than men (Hagan \& Kay, 2007), women should be committing more crime than men. However, research has shown that this is not the case. After analyzing the relevant literature on strain theory, Broidy and Agnew (1997) argued that GST could not explain the differences between men and women in regard to their crime commission simply by saying that men experience more strain than women. As a result, 
they offer three insights to explain the higher crime commission rates for men compared to women. Broidy and Agnew (1997) divided their argument following the three different types of strains proposed by Agnew (1992). In regard to positively valued goals, men were found to value monetary and material success, and job advancement and recognition, whereas women were found to value relationships with others and their work/life balance more. Consequently, the authors argued that men were more likely to experience financial strains and work strains compared to women who were more likely to experience relationship strains. Broidy and Agnew (1997) used the other two types of strains to demonstrate that women were more likely to experience gender discrimination at work in regard to their "gender role", whereas men were more likely to experience conflict caused by relationship with others who they are competing against in the workplace. As a result, men were more likely to be confrontational in dealing with work strains. They were more likely to respond using aggressive behavior, violence and crime whereas women were more likely to experience strains which they coped with using selfdestructive acts or ways to avoid that strains such as self-harm, drug use, eating disorder or even selective ignorance.

One has to keep in mind how men and women differ in their emotional response to strain. In his survey of 2,816 men and women from ages 18 to 65, Matud (2004) found that women exhibited higher stress, more minor daily stressors and rated their life events as more negative and less controllable compared to men. Additionally, women reported that family and health related events were the most stressful events in their lives. Men 
reported relationships, finance and work events to be the most stressful. Men were found to be more detached and had more control over their emotional reactions to stressful events compared to women who had more emotional and psychological distress in response to stress. This may help explain why men and women differ in how they cope with strain.

Coping with strain can be based on the distinction between other-directed emotions and self-directed emotions. Broidy and Agnew (1997) presented evidence about how men and women differed in their emotional response to strain. They base their argument on Agnew's (1992) distinction between other-directed emotions and selfdirected emotions. Other-directed emotions are related to anger, and aggressive and violent behavior whereas self-directed emotions are more along the lines of internal coping such as depression and anxiety. Jang (2007) evaluated Broidy and Agnew’s (1997) arguments about applying GST to explain gender differences in crime and deviance. The author used multiple waves of data from the National Survey of Black Americans between the late 1970's and the early 1990's. Broidy and Agnew's first argument was that men and women experienced different types of strains. The data showed that African American women were more likely to report physical health strains, interpersonal relations strains, gender role strains, and financial strains compared to men who reported work-related strains, racial strains, job strains and financial strains. The second argument was that men and women differed in their emotional and behavioral responses to strain. The authors found that women were more likely to generate self- 
directed strains such as depression and anxiety than other-directed emotions such as anger.

Overall, results showed that strained individuals were more likely to use legitimate coping mechanisms when they experienced self-directed emotions in response to strain. Thus, while men and women respond differently to strain, women have been found to report higher levels of anger, depression and anxiety compared to men. The reason why women are not coping with strains and their higher levels of depression and anxiety by committing more crime is probably because women and men differ in the type of anger they experience. Women's anger is often associated with feelings of fear, guilt, shame, anxiety whereas men's anger is often associated with violence and resentment. Mirowsky and Ross (1995)'s study about gender differences in emotional expression revealed that women reported higher levels of anger, depression and anxiety compared to men. In other words, it seems as if women's anger is mitigated by other forms of emotions (fear, anxiety, and shame). Women seem to internalize their anger more than men, therefore causing them not to respond to strains with crime and deviance. Eitle (2002) followed the study conducted by Broidy and Agnew (1997) in which they reported several strains experienced by women which had an impact on their deviance. Eitle's (2002) study aimed to analyze the impact of women's perception of gender-biased unfair treatment on their deviance. He found that women who perceived that they have been a victim of gender-based discrimination were more likely to be involved in crime and more likely to be substance users. This study's findings showed that when people 
believe that they have been treated unfairly, they are more likely to respond by being involved in crime and substance use. This is consistent with Agnew's GST. Nonetheless, GST has been used as a theoretical framework for studies looking at the negative emotions stemming from strains (De Coster \& Zito, 2010; Moon \& Johnson, 2012; Piquero, 2015). Thus, GST can be used in studies not only looking at deviance, but also at negative emotions resulting from straining situations.

This dissertation is looking at first-generation lawyers and biological sex to determine if there is a direct relationship between these variables and workplace discrimination (understood as a strain) and job satisfaction. The potential indirect relationship between these variables and job satisfaction will also be assessed. Additionally, this dissertation aims to assess the direct effects of biological sex and firstgeneration lawyers on job satisfaction. The idea behind the dissertation is determining the extent of the relationship between workplace discrimination experienced by lawyers (especially women and first-generation lawyers) and how it has impacted their perception of job satisfaction.

Workplace discrimination is understood as a strain as it could take the shape of any of the three strains that were presented by Agnew and others. Those strains are important to consider since they can impact someone's life and someone's work in a negative way. In the legal profession specifically, lawyers are likely to experience all three of the strains described by Agnew (1992). For instance, as being a partner would greatly advance their career, not being offered partnership is an example of "preventing 
the achievement of positively valued goals". Secondly, when opportunities are taken away by not being put on a case, being removed from a case, or being laid off are examples of "removal from positively valued goal". Lastly, when one is victim of a toxic work environment where sexist jokes are made, sexual comments or advances are made, one is "presented with negatively valued stimuli". To this date, no study has examined the link between workplace discrimination, understood as strain, and job satisfaction among lawyers based on gender and first-generation. This dissertation is a modest contribution to filling the gap in the literature on the relationship between workplace discrimination and job satisfaction for lawyers. Similar to Amponsah-Tawiah, Annor and Arthur (2016), whose study used structural equation modeling to determine the direct and indirect effects of commuting stress on employees' job satisfaction and turnover retention through burnout, this dissertation uses structural equation modeling to determine the direct and indirect effects of gender and first-generation lawyers on lawyers' job satisfaction through workplace discrimination. The following diagram explains the different relationships that this dissertation is trying to assess. 


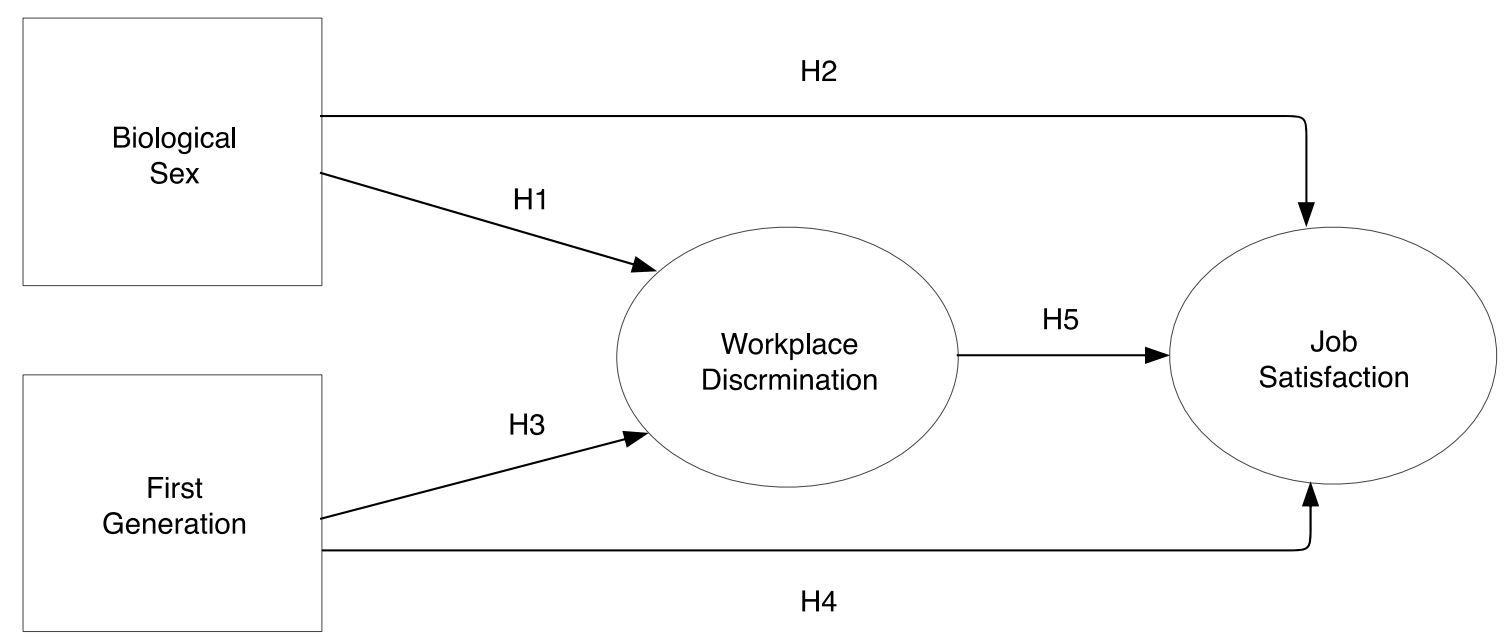

Figure 1. Hypotheses Model

For this dissertation it is important to address several hypotheses:

H1. Gender will have a direct effect on job satisfaction. In other words, it is hypothesized that female lawyers will be more dissatisfied with their job compared to male lawyers.

H2. Gender will have an indirect effect on job satisfaction through workplace discrimination. It is hypothesized that female lawyers will experience more instances of workplace discrimination compared to male lawyers, which then will have a negative impact on their job satisfaction.

H3. First-generation lawyers will have a direct impact on job satisfaction. It is hypothesized that first-generation lawyers will be more dissatisfied with their job.

H4. First-generation lawyers will have an indirect impact on job satisfaction through workplace discrimination. In other words, first-generation lawyers will 
experience more instances of workplace discrimination, which in turn will negatively impact their job satisfaction.

H5. It is hypothesized that workplace discrimination will have a direct effect on job satisfaction. 


\section{CHAPTER III - METHODS}

Data

This study uses the Inter-University Consortium for Political and Social Research (ICPSR) data entitled After the JD (AJD) - Wave 1: A Longitudinal Study of Legal Careers in Transition Data Collection: May 2002-May 2003, United States (Garth, Sterling, \& Sander, 2013). Surveys were distributed via three avenues: mail, phone or Internet. This project used surveys that were sent to 5,000 lawyers during their first two to three years of practice after they graduated law school. The selected sample $(\mathrm{N}=$ 5,000 ) represents $10 \%$ of the total number of people who became layers in 2000. More than 50,000 became lawyers since. These 5,000 lawyers practiced in 18 different geographic areas across the United States. The idea was to have a stratified random sample of new attorneys from different areas to mirror the national population of new attorneys. Lawyers were samples from eighteen geographic areas across the United States, including the four largest legal markets of New York, Washington D.C., Chicago and Los Angeles and fourteen other areas ranging from entire states to small metropolitan areas. To better explore issues of race and ethnicity, the authors decided to conduct a minority oversample which led to an additional 600 African American, Hispanic and Asian respondents being surveyed. Following the initial mailing of surveys in May 2002, mail and telephone surveys were used to follow up with non-respondents. In addition, 
about 100 in depth face-to-face interviews were conducted with a subset of respondents (Dinovitzer \& Garth, 2007). Of the original sample of attorneys who were located and met the inclusion criteria, the response rate was $71 \%$ which represented a total of 4,538 valid responses. The 4,538 valid responses combined the national sample of 3,905 individuals and a minority oversample of 633 respondents. $46 \%$ of the AJD sample were women, and $17 \%$ were non-white. Lastly, the study authors noted that $A J D$ would, in the future, supplement findings by sending follow-up questionnaires and conduct face to face interviews with $10 \%$ of the survey respondents within six to ten years of these lawyers' practice (Dinovitzer \& Garth, 2004).

Surveying a large number of lawyers across the United States allows researchers to have a better idea of the national sample of lawyers. Asking a variety of questions using surveys will increase our understanding of how legal careers start, which environment and skill sets are more prone to goal achievement for young attorneys and how different opportunities may present themselves based on a variety of demographic characteristics such as race, ethnicity, age and gender. Thus, survey instruments will help gather both personal and professional information relative to legal careers and lawyers' experiences (Dinovitzer \& Garth, 2004).

Survey research was employed for this project. Survey data is beneficial in regard to reaching a wide pool of individuals. Specifically, lawyers have to register when they start practicing. Therefore, it is easy to find their information and contact them (Dinovitzer \& Garth, 2004). Using surveys has a relatively low cost and takes little time 
and effort to be conducted (Hagan, 1982). Since the target population works in the legal profession, and the research concerns them and their experience in the first ten years of their career, the legitimacy of the study should have a positive impact on how interested participants will be to contribute to a better understanding of the stratified construction of the legal profession.

Most studies about job satisfaction use a cross-sectional design. Hagan and Kay (1995) argued that this methodological strategy only allows to study a person's job satisfaction at a single moment in their life. Therefore, given that job satisfaction is very subjective, there is a need for longitudinal studies to examine the relationship between individuals' characteristics and job satisfaction (Hull, 1999). When assessing employees' attitude, Saari and Judge (2004) recommended using either of the most extensively validated survey measures for job satisfaction. These survey measures of job satisfaction are the Job Descriptive Index (JDI) developed by Smith, Kendall and Hulin in 1969, and the Minnesota Satisfaction Questionnaire (MSQ) developed by Weiss, Dawis, England and Lofquist in 1967. The JDI assesses five different facets of job satisfaction. These facets are work, pay, promotion, coworkers, and supervision. The scale contains 72 items with 9 to 18 items for each subscale. For each facet, a short description is provided followed by the appropriate items for that facet. Each item is composed of a phrase or an assessment-type adjective. Respondents respond using "yes", "no" or "uncertain or cannot decide". The JDI has been used countless times. Validation evidence has been reported in studies that used the JDI. For instance, in their review of 249 measures of 
work experience, Cook, Hepworth, Wall and Warr (1981) reported validation evidence in over 100 studies that were using the JDI. One limitation is that the scale is limited to only five facets. Additionally, Cook et al. (1981) argued that the five-facet scale may not be applicable for all types of employees. Despite these limitations, the JDI remains one of the most popular ways to measure job satisfaction.

The MSQ is another popular way to measure employee's job satisfaction. Compared to the JDI which examines five facets, this model encompasses 20 different facets. The MSQ possesses two different formats. The first one, or long one, is composed of 100 items (five items for each facet). The second one, or short one, is composed of 20 items (one item for each facet). The MSQ relies on the notions of extrinsic and intrinsic aspects of job satisfaction. Extrinsic aspects being related to pay for example, or things other than the tasks performed. The intrinsic aspects are related to the nature of the job and how people feel about the kind of work they accomplish. The short MSQ seems to be a little more specific compared to the JDI as each facet is divided into several components. For example, supervision is measured using satisfaction with human relations and satisfaction with technical competence. While this model has received support, critics argue that the content of extrinsic and intrinsic subscales can be problematic. High correlations between the subscales has been found. Wexley, Alexander, Greenawalt, and Couch (1980) studied similarities and differences in job satisfaction and performance evaluation between managers and "subordinates". They used 194 students from two universities who were employed and had an immediate 
manager. The authors gave respondents the MSQ and the JDI. They found that the more knowledgeable a manager was of a subordinate's work-related attitudes, the more positively the subordinate were to evaluate the manager. Moreover, the more the subordinates knew about managers' attitudes, the more satisfied they were with supervision from their manager. Nevertheless, the authors found correlations between the subscales for the MSQ. This calls into question whether these subscales are measuring the same construct. Keeping the criticism in mind in regard to collinearity issues, it might be better to use the short, rather than the long, version of MSQ. To avoid any collinearity issues between subscales, this study uses the JDI as a measurement of job satisfaction.

\section{Measures}

\section{Dependent variable}

The dependent measure for this study is job satisfaction. Although some defined it as "work satisfaction", many studies have measured the dependent measure the same way I am in the dissertation or used terms interchangeably (Applebaum et al., 2010; Hall, 1995; Rode, 2004; Heinz et al., 1999). For instance, Mueller and Wallace (1996) used satisfaction with work conditions and rewards to assess the relationship between job satisfaction and gender (i.e. they used work satisfaction and job satisfaction interchangeably). In the $A J D$ questionnaire, respondents were asked to rate their satisfaction regarding 16 specific aspects of their jobs. The survey question was: How satisfied are you with each of the following aspects of your current position? To rate their satisfaction, respondents were given a continuum, ranging from 1 highly dissatisfied with 
their job to 7 highly satisfied with their job. Thus, the higher the score, the more satisfied with their job. Looking at different aspects of someone's job to determine their level of satisfaction corresponds to the facet approach defined by Spector (1997).

Measuring job satisfaction following the JDI facet approach is the most popular way to determine employee's satisfaction. Measuring job satisfaction has several benefits not only from an individual perspective but also for the organization. Especially in the context of workplace discrimination, job satisfaction will be a good way to measure how employees feel in the organization, how likely they are to be happy with the job they are performing, and how likely they are to stay in that position (Cook et al., 1981). Additionally, since no research has been conducted on the effect of workplace discrimination on job satisfaction among first-generation lawyers, following the way job satisfaction has been measured in other contexts will help with clarity and effectiveness.

According to Spector (1997), job satisfaction is comprised of five different facets. Additionally, Garth and colleagues (2004) collected their data in such a way that those measures appeared pivotal in the questionnaire assessing job satisfaction. The After the $J D$ data is composed of several variables that encompass the construct of job satisfaction. They are likert-type scales variables ranging from 1 highly dissatisfied to 7 highly satisfied. The first independent measure is Supervision. It contains items depicting how satisfied they are with recognition they received for their work, control over the amount of work they have to do, control over how they do their work, and the performance evaluation process. The second variable is Work. Items for this measure reflected 
satisfaction with respondents' level of responsibility, substantive area of work, different tasks performed, intellectual challenge of work, and opportunities for building skills. The third variable is Extra. It encompasses items referring to satisfaction with relationships with colleagues, opportunities for pro bono work, amount of travel and diversity in the workplace. The last measure is Promotion. It reflects the amount of recognition being given to an employee, which is materialized as opportunities for advancement in the organization and compensation such as salary, benefits and bonus, if applicable.

These facets offer a good view of what constitutes job satisfaction. However, these five measures do not account for other phenomena that may influence someone's perception of job satisfaction (Cook et al., 1981). Spector (1997) highlighted the different ways that theoretical constructs of job satisfaction have positive and negative consequences. But overall, researchers agree that these constructs have validity. Thus, the JDI version of job satisfaction provides a set of questions that include different facets of a job which have been found to be important for most employees and have been used hundreds of times compared to the MSQ. This reflects credibility and validity (Cook et al., 1981; Saari \& Judge, 2004; Spector, 1997, Weiss et al., 1967). To assess the reliability of our multi-item job satisfaction model, Cronbach's alpha will be utilized. Cronbach's alpha has been widely used to measure internal consistency, that is how much multiple items measure the same construct (Tavakol \& Dennick, 2011). To determine internal consistency, this dissertation will use the alpha coefficient standard of .70 (Cortina, 1993). 


\section{Independent Variables}

In order to determine the relationship between workplace discrimination and job satisfaction for lawyers, it was critical to assess discrimination. Discrimination encompassed a variety of discriminating experiences at work (Garth et al., 2004).

Respondents were asked if in the last two years they had experienced one or more forms of discrimination in their place of work by virtue of their race, religion, ethnicity, gender, disability, or sexual orientation. The different forms of discrimination were: experienced demeaning comments or other types of harassment, missed out on desirable assignment, had client request someone other than you to handle the matter, experienced one or more other forms of discrimination. The independent variable Gender was dichotomized were females were coded 1 and males were coded 0. First-Generation was assessed using information about parents or guardians' highest level of education which was dichotomized where 1 referred to respondents' relatives' highest level of education not being a law degree (JD) and 0 referred to respondents' parents or guardians' highest level of education being a law degree (JD).

\section{Missing data}

Missing data is a recurring issue, especially for researchers who use statistical techniques such as multiple regression (Enders, 2001b). Schafer and Graham (2002) defined missing value as a lack of response. According to Rubin (1976) there are three ways for missing data to occur: missing at random (MAR), missing completely at random (MCAR), and missing not at random (MNAR). Rubin (1976) defined MAR as the 
probability that the data are missing due to the observed data ( $\left.\mathrm{Y}_{\mathrm{obs}}\right)$ only. Dong and Peng (2013) described that MCAR is a special case of MAR. In this case, the likelihood of missing data does not depend on the observed data $\left(\mathrm{Y}_{\mathrm{obs}}\right)$ or on the missing part $\left(\mathrm{Y}_{\mathrm{mis}}\right)$. MNAR occurs when the likelihood of missing data depends on the missing value itself.

Dong and Peng (2013) presented the following equation to better understand how missing data works: the observed part of the data is $\left(\mathrm{Y}_{\mathrm{obs}}\right)$ and the missing part is $\left(\mathrm{Y}_{\mathrm{mis}}\right)$ so the data matrix $\mathrm{Y}=\left(\mathrm{Y}_{\mathrm{obs}}, \mathrm{Y}_{\mathrm{mis}}\right)$. MAR occurs when the probability that data are missing, after controlling for $\mathrm{Y}_{\mathrm{obs}}$ are based on the observed part of the data $\left(\mathrm{Y}_{\mathrm{obs}}\right)$ and not the missing part $\left(\mathrm{Y}_{\mathrm{mis}}\right)$. For instance, in cases where a question about income is asked, missing data is likely to be MNAR as respondents earning high income are more likely not to disclose that information compared to people who make less money. Dong and Peng (2013) presented evidence that missing data take place at two different levels. At the unit level, missing data happens when a respondent does not take part in a survey. At the item level, missing data is related to incomplete information given by survey respondents. At the item level, missing data resembles a respondent not answering one or two questions but answering the rest of the survey. Dong and Peng (2013) argued that missing data at the item level should be looked at through three different lenses: the proportion of missing data, the missing data mechanisms, and the patterns of missing data. After these three aspects are addressed, then a researcher can choose how to deal with missing data for that particular study. 
The proportion of missing data is related to the quality of statistical inferences. To show the validity of statistical inferences, there needs to be an acceptable percentage of missing data in a particular data set (Dong \& Peng, 2013). Unfortunately, the literature does not present a threshold for what is an acceptable percentage of missing data in a data set (Dong \& Peng, 2013). Bennett (2001) argued that when $10 \%$ of the data are missing, the statistical inferences are likely to be biased. Schafer (1999), presented evidence that when $5 \%$ or less of the data is missing, it should be considered negligible. As a result, the proportion of missing data should not be the only way to assess the missing data issue in a data set. Tabachnick and Fidell (2012) demonstrated that to show validity in statistical inferences, missing data mechanisms and missing data patterns have to be taken into consideration as well. The missing data mechanisms mentioned by Tabachnick and Fidell (2012) are referred to the three mechanisms discussed above by Dong and Peng (2013): MAR, MCAR and MNAR. The patterns of missing data mentioned by Tabachnick and Fidell (2012) referred to three different types of patterns: univariate, monotone and arbitrary also described by Dong \& Peng, 2013. Dong and Peng (2013) demonstrated that univariate pattern of missing data refers to the idea that the same participants have missing data on one or more of the variables in the data set. The monotone pattern of missing data reflects the idea that, especially in longitudinal studies, when a participant stops participating in the study, his or her answers (data) will be missing from the drop out point forward. Arbitrary missing data pattern occurs when the missing data is present for any variable and for any participant in a randomized fashion. According to Dong and 
Peng (2013) univariate and monotone patterns of missing data are easier to manage compared to arbitrary patterns. MCAR can be perceived as "a random ample of the complete data" (Dong and Peng, 2013, p. 2). Not paying attention to MCAR is not likely to introduce bias but it will increase the standard errors of the sample estimates because the sample size is reduced. Moreover, the literature highlights that MCAR is a lesser threat to statistical inferences compared to MAR and MNAR (Dong \& Peng, 2013). Little and Rubin (2002) defined Multiple imputation (MI) as one of the most popular methods to present valid statistical inferences while dealing with missing data, specifically MAR. In their book, Little and Rubin (2002) demonstrated that MI allows to impute missing data, even though there is uncertainty about the imputed values. The authors explain that the uncertainty about the imputed variables is associated with the creation of a set of $m$ possible values for each unobserved data point. MI imputes missing data $m$ times so the researcher will have $m$ complete data sets where the set of $m$ variables provides a unique estimate for each missing value. When the $m$ data sets are complete, they are analyzed independently for each parameter using standard statistical techniques. The $m$ estimates for each parameter will be different. But at the end, the $m$ estimates will be grouped together to create one single estimate for the parameter of interest which will have its own standard error. The standard error for the parameter of interest takes into consideration the uncertainty caused by the imputation of an estimated value. As a result, that standard error is likely to be larger than a standard error from a single imputation method. 
Missing data should be kept to a minimum when data collection is designed and implemented by researchers. When there is missing data, researchers have to analyze the missing data mechanisms, missing data rates, missing data patterns, and missing data distribution. Then they can choose which missing data method to use. When there is missing data, researchers must also acknowledge it, explain why there is missing data in the study, and explain the method used to handle missing data. (Graham, 2009).

Maximum likelihood (ML) estimation refers to the probability of the data as being a combination of the data itself and unknown parameters (Allison, 2002). In other words, assuming that all observations are independent, the overall likelihood for the sample equals all the likelihoods for all the observations. However, in the case that the missing data is MAR, the likelihood is obtained by adding all the likelihoods and divide the number by all the possible values of missing data. ML can be used in order to estimate linear models that assume that the data come from a multivariate normal distribution (Allison, 2002). The idea of using ML in presence of missing data has been discussed since the 1950's (Anderson, 1957). However, it was not until recently that structural equation modeling software included ML in their package (Enders, 2001a; Enders \& Bandalos, 2001). The idea behind ML is that it helps describe a distribution for a population data. Assuming multivariate normality of the data, Enders and Bandalos (2001) described full information maximum-likelihood (FIML) as a case wise likelihood function that solely uses observed variables for a specific case. Thus, in a structural equation model with different levels of nonnormality and missing data in the indicators, 
FIML assumes that the incompletely observed variables are linearly related to the completely observed variables. More simply, in presence of multivariate normal data, ML uses the probability density function to describe the shape of a multivariate normal distribution (Enders, 2001a). Specifically, assuming multivariate normality, the density function is composed of a score called a vector score and multiple population parameter values. This density function (with its score and population parameter values) corresponds to a likelihood value that quantifies the probability of drawing an individual's scores from a multivariate normally distributed population (Enders, 2001a).

Dong and Peng (2013) defined FIML as "a model-based missing data method that is used frequently in structural equation modeling" (p. 11). Moreover, Enders and Bandalos' (2001) used MCAR and MAR simulations to determine the performance of FIML in comparison to other missing data techniques for structural equation models. They found that FIML estimates were the least unbiased and the most efficient for both MCAR and MAR simulations. This dissertation uses structural equation modeling and FIML to handle missing data.

\section{Data Analysis Plan}

This dissertation follows a series of steps. The first step is descriptive statistics. Descriptive statistics describe the distribution of the data. Measures of central tendency such as the mean, mode, and median express a summary statistic to describe the distribution of scores in the data. Thus, after measuring the central tendency of the distribution, it is important to report the spread of the distribution using standard 
deviation. The standard deviation is a measure of variability (Altman \& Bland, 2005) and is calculated using the square root of the sum of the squared deviations from the mean (Babbie, 1990; Hagan, 1982; Mertler \& Vannatta, 2016).

The second step of the analysis is composed of bivariate statistics. Bivariate statistics analyze two variables simultaneously. Correlation is a statistical technique that can determine whether and how strongly pairs of variables are related. Correlations are appropriate for quantifiable data where numbers mean something. The correlation coefficient ranges from -1 to 1 . The closer it is to -1 or 1 , the more closely the two variables of interest are related. If it is close to 0 there is no relationship between the two variables (Hagan, 1982). When using Pearson's correlation coefficient, several assumptions must be met by the data. Variables have to be measured at the interval or ratio level. $\mathrm{X}$ and $\mathrm{Y}$ variables have to be normally distributed in the population. The relationship between $\mathrm{X}$ and $\mathrm{Y}$ should be linear. Lastly, a probability sample was drawn from the population (Asuero, Sayago \& Gonzalez, 2006). The AJD data used in this dissertation meets the Pearson's $r$ assumptions in that it is a probability sample with interval-ratio level variables (which is somewhat linear), and almost all variables are normally distributed in the population. Correlations are important when comparing the effect of different variables in a data set (Bagozzi, 1982). A correlation matrix is important to the study as we need the correlation coefficients for the variables related to job satisfaction in the confirmatory factor analysis. (Hagan, 1982). 
The third step is multivariate statistics, specifically, structural equation modeling (SEM). SEM is a family of statistical analysis techniques that look at structural relationships (Dong \& Peng, 2013; Hagan, 1982; Muthén, \& Muthén, 1998-2006). SEM is important to this study because it gives an estimation of the numerous interrelated measure dependences in one analysis. (Bagozzi \& Yi, 2011). Therefore, this dissertation presents results from a confirmatory factor analysis (CFA) via SEM using the SEM software Mplus. CFA is a statistical technique which helps test a hypothesized structure among different measures. In other words, CFA is a depiction of the theory in which it shows how measured variables should be grouped together to fit the theory (Hagan, 1982). Fit statistics and factor loadings are important when conducting CFAs (Kline, 2004). Thus, to evaluate the CFA in this dissertation, model fit statistics are presented to determine if the hypothesized model fits the data. To do so, the dissertation follows $\mathrm{Hu}$ and Bentler's (1999) recommendations that chi-square should not be significant, Secondly, the Root Mean Square Error of Approximation (RMSEA) which is a parsimony-corrected index possessing a 90\% confidence interval (Steiger, 1990) should be comprised of values under .10, and a very good fit should be comprised of values under .05 (Kelloway, 1998, p.27). Thirdly, the Bentler Comparative Fit Index (CFI) developed by Bentler (1990) should be .95 and up (Hu \& Bentler, 1995, p. 85). The last fit index is the standardized root mean square residual (SRMR) which corresponds to a statistic related to correlation residuals. An SRMR value of .05 should indicate a good model fit (Kelloway, 1998, p. 27; Kline, 1998, p. 129). These fit indices will be 
calculated by the SEM and will determine proper model fit. In addition, factor loadings should be large when using SEM. Kline (2004) argued that factor loadings of .50 are considered large enough. This dissertation will use the .50 standard for factor loadings.

In the SEM family, this dissertation also uses a structural model to show how constructs are related to one another. The structural model shows if the "grouping" fits the theory (Dinovitzer \& Garth, 2007; Heinz et al., 1999). Model statistics in SEM are evaluated following the conventional level of statistical significance that is $\alpha=.05$ (Kline, 1998).

Factor loadings explain how much a variable has contributed to a specific factor (Kline, 1998). While unidimensionality of the factor is an issue for exploratory factor analysis and principal component analysis, in this dissertation, confirmatory factor analyses are performed. Unidimensionality is not the biggest issue in confirmatory factor analysis as it examines the dimensionality of a job satisfaction (i.e. a construct with more than one dimension). Thus, the larger the factor loading, the higher the contribution from a variable to the factor of interest (Harman, 1976). Consequently, if a model is reasonably correct, all indicators measuring a common factor should have high standardized factor loadings on that factor (e.g. >.70) (Kline, 1998). This provides the model with convergent validity. The model should also possess not very high estimated correlations between factors (e.g. <.90 in absolute value) to provide the model with discriminant validity (Kline, 1998). The following table provides an outline of the data analysis. 


\section{Table 1}

Analytic Plan

\begin{tabular}{|c|c|c|}
\hline Nature of Analysis & Hypothesis or Proposition Tested & Procedure \\
\hline \multirow[t]{2}{*}{$\begin{array}{l}\text { Step 1: } \\
\text { Descriptive } \\
\text { Statistics }\end{array}$} & $\begin{array}{l}\text { How are the scores distributed in } \\
\text { the data? }\end{array}$ & $\begin{array}{l}\text { Measures of central } \\
\text { tendency (mean, mode, } \\
\text { median) }\end{array}$ \\
\hline & $\begin{array}{l}\text { What is the spread of the } \\
\text { distribution? }\end{array}$ & Standard deviations \\
\hline \multirow[t]{3}{*}{$\begin{array}{l}\text { Step 2: Bivariate } \\
\text { Statistics }\end{array}$} & $\begin{array}{l}\text { What is the effect of different } \\
\text { variables in the data set? }\end{array}$ & Correlations \\
\hline & $\begin{array}{l}\text { Are certain variables linked to one } \\
\text { another? }\end{array}$ & \\
\hline & $\begin{array}{l}\text { What is the strength and direction } \\
\text { of the links between variables? }\end{array}$ & \\
\hline Step 3: & How does the model fit the data? & Confirmatory Factor \\
\hline $\begin{array}{l}\text { Multivariate } \\
\text { Statistics/ } \\
\text { Confirmatory } \\
\text { factor Analysis }\end{array}$ & $\begin{array}{l}\text { What are the factor loading sizes } \\
\text { of the model? (for gender, first- } \\
\text { generation, workplace } \\
\text { discrimination and job satisfaction) }\end{array}$ & $\begin{array}{l}\text { Analysis/Measurement } \\
\text { model }\end{array}$ \\
\hline $\begin{array}{l}\text { Step 4: } \\
\text { Multivariate } \\
\text { Statistics/ } \\
\text { Structural Model }\end{array}$ & $\begin{array}{l}\text { How are certain constructs related } \\
\text { to one another? (Fit indexes, factor } \\
\text { loadings) (for gender, first- } \\
\text { generation, workplace } \\
\text { discrimination and job satisfaction) }\end{array}$ & Structural model \\
\hline $\begin{array}{l}\text { Step 5: Sensitivity } \\
\text { Analysis }\end{array}$ & $\begin{array}{l}\text { What are the direct effects models? } \\
\text { What are the indirect effects } \\
\text { models? }\end{array}$ & Alternative models \\
\hline
\end{tabular}




\section{CHAPTER IV - RESULTS}

This dissertation, using SEM followed a series of steps. The following section reports the findings of the descriptive statistics.

\section{Step 1}

The first step of the analysis examines the descriptive statistics and the psychometric properties of the variables composing job satisfaction. Specifically, the mean, standard deviation, skewness, and kurtosis for each variable is reported. Cronbach's Alpha is also reported to show internal consistency of the job satisfaction model.

\section{Table 2}

\section{Descriptive Statistics}

\begin{tabular}{lcccccc}
\hline \multicolumn{1}{c}{ Variable } & Means & S.D. & Min & Max & Skewness & Kurtosis \\
\hline Bio Sex & .46 & .50 & 0 & 1 & .17 & -1.97 \\
First Gen & .64 & .48 & 0 & 1 & -.57 & -1.67 \\
Disc. Comments (D1) & .13 & .35 & 0 & 1 & 2.20 & 2.82 \\
Disc. Missed (D2) & .08 & .28 & 0 & 1 & 3.04 & 7.22 \\
Disc. Request (D3) & .08 & .29 & 0 & 1 & 3.01 & 7.06 \\
Disc. Other (D4) & .10 & .31 & 0 & 1 & 2.62 & 4.85 \\
Super & 4.63 & 1.21 & 1 & 7 & -1.26 & 1.31 \\
Work & 4.97 & 1.25 & 1 & 7 & -1.44 & 1.55 \\
Extra & 4.24 & 1.31 & 1 & 7 & -.83 & .48 \\
Promo & 4.24 & 1.55 & 1 & 7 & -.69 & -.28 \\
\hline
\end{tabular}

Results from the descriptive statistics show that the distribution of each variable of interest in this study is normal or nearly normal except for biological sex and all four 
measures of workplace discrimination. For these variables, their standard deviations are greater than their means. D2 (missed out on desirable assignment) and D3 (had client request someone other than you to handle the matter) are slightly above the standards of skewness defined by Sheskin (2007). Lastly, the four measures of job satisfaction present a Cronbach's alpha of . 78 which shows internal consistency of the job satisfaction model.

Step 2

Table 3

Correlation Matrix

\begin{tabular}{lcccccccccc}
\hline & $\begin{array}{c}\text { Bio } \\
\text { Sex }\end{array}$ & $\begin{array}{c}\text { First } \\
\text { Gen }\end{array}$ & D1 & D2 & D3 & D4 & Super & Work & Extra & Promo \\
\hline Bio & 1.00 & & & & & & & & & \\
Sex & & & & & & & & & & \\
First & & & & & & & & & & \\
Gen & -0.01 & 1.00 & & & & & & & & \\
D1 & 0.20 & -0.01 & 1.00 & & & & & & & \\
D2 & 0.13 & -0.03 & 0.34 & 1.00 & & & & & & \\
D3 & 0.08 & 0.01 & 0.15 & 0.12 & 1.00 & & & & & \\
D4 & 0.15 & 0.01 & 0.49 & 0.41 & 0.21 & 1.00 & & & & \\
Super & -0.05 & 0.01 & -0.06 & -0.09 & 0.06 & -0.06 & 1.00 & & & \\
Work & -0.03 & 0.01 & -0.00 & -0.03 & 0.08 & 0.00 & 0.85 & 1.00 & & \\
Extra & -0.05 & 0.01 & -0.05 & -0.03 & 0.07 & -0.04 & 0.73 & 0.69 & 1.00 & \\
Promo & -0.10 & -0.00 & -0.04 & -0.03 & 0.01 & -0.07 & 0.70 & 0.68 & 0.60 & 1.00 \\
\hline
\end{tabular}

Results from the correlation matrix demonstrate that all measures of job satisfaction and all measures of discrimination share variance, suggesting that the model possesses convergent validity (Campbell \& Frisk, 1959). Table 3 shows that biological sex is weakly and positively correlated with D1 $(r=.20)$. In other words, female lawyers are more likely to experience demeaning comments and other types of harassment 
compared to male lawyers. Regarding measures of discrimination, the relationships between $\mathrm{D} 1$ and $\mathrm{D} 2$ is weak and positive $(\mathrm{r}=.34)$ and between $\mathrm{D} 1$ and $\mathrm{D} 4$ is moderate and positive $(\mathrm{r}=.49)$. This suggests that lawyers who experience demeaning comments and other types of harassment are also likely to miss out on desirable assignments and experience one or more other forms of discrimination. The link between D4 and D2 is moderate and positive $(r=.41)$ and the link between D4 and D3 is weak and positive $(r=$ .21) which means that lawyers who miss out on desirable assignments and had a client request someone else to handle a matter are also likely to experience one or more other forms of discrimination.

For measures of job satisfaction, Table 3 presents several strong and very strong correlations. For instance, the link between satisfaction with supervision and satisfaction with work is very strong and positive $(\mathrm{r}=.85)$. Thus, lawyers who are very satisfied with their supervisors are also likely to be very satisfied with their work. The link between satisfaction with supervision and extra is strong and positive $(\mathrm{r}=.73)$. Lawyers who are satisfied with their supervisors are also likely to be satisfied with other aspects of their job such as pro bono opportunities, amount of travel and diversity in the workplace. Table 3 also shows that the links between work and extra $(r=.69)$ and work and promotion $(\mathrm{r}=.68)$ are strong and positive. In other words, lawyers who are satisfied with their work are also likely to be satisfied with other aspects of their jobs and promotion. Lastly, the link between extra and promotion is strong and positive $(r=.60)$. 
Lawyers who are satisfied with extra aspects of their work are likely to be satisfied with promotion.

Surprisingly, while the relationship between the overall constructs of job satisfaction and workplace discrimination is in the expected direction (negative), it is very weak ( $\mathrm{r}$ ranging from -.09 to .08 ). The same is true for first generation lawyers. Contrary to what was expected, the correlation coefficients for first generation and the variables encompassing both workplace discrimination and job satisfaction constructs are very weak, ranging from -.3 to .01 .

\section{Step 3}

The measurement model for this study demonstrated a good fit of the data (see Table 1). Specifically, the chi-square estimate is statistically significant (chi-square = 133.03, $\mathrm{p}=0.00$ ) suggesting a misfit of the model to the data. However, Schumaker and Lomax (1996) argued that chi-square is sensitive to sample size and may present misleading results. Thus, additional statistics were consulted and indicated a good model fit to the data. These results suggest that the CFA model present good construct validity for the measures used in this study (Gibbs, Giever, \& Higgins, 2003; Hu \& Bentler, 1999 and Kelloway, 1998 for a description of the fit statistics and their standards). 


\section{Table 4}

\section{Selected Fit Indexes for the CFA Model}

\begin{tabular}{lcc}
\hline Index & Value & Standard \\
\hline CFI & .98 & $\geq .95$ \\
RMSEA & .04 & $\leq .10$ \\
WRMR & 1.67 & 1.00 \\
Chi-Square & $\mathrm{p}=.000$ & $\mathrm{p}=.05$ \\
\hline
\end{tabular}

The measurement model shows that the factor loadings for the observed indicators are all above Kline's (1998) standard of 0.50 for a large factor loading, with the exception of one indicator. The third measure of discrimination Had a client request someone other than you to handle the matter does not provide a large factor loading (.42). This measure was retained because of empirical relevance to the present study. All factor loadings are statistically significant at the 0.00 level. The size and significance of the factor loadings suggest that the measures for this dissertation are suitable indictors of their latent measures. In this case, workplace discrimination and job dissatisfaction. The measurement model suggests that for one unit increase in workplace discrimination, there is a decrease in job satisfaction. 


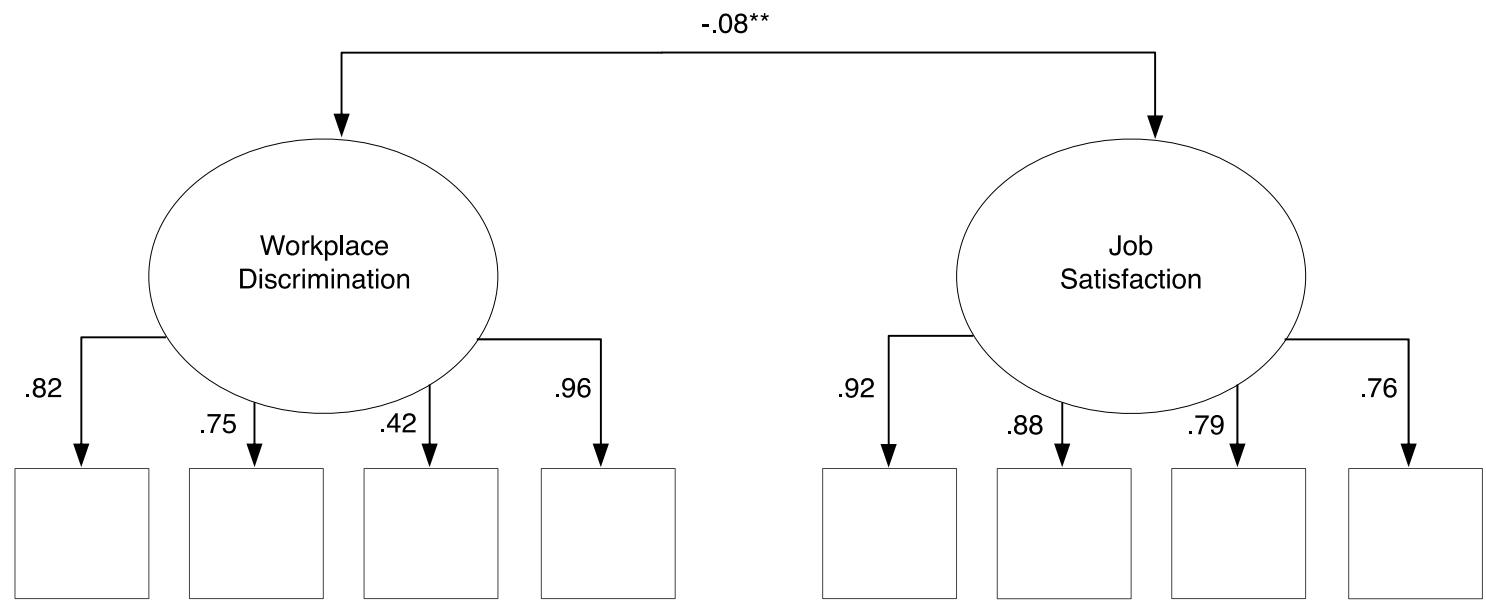

Figure 2. Measurement Model.

Step 4

To examine whether the link between biological sex and first generation and job satisfaction is mediated by workplace discrimination, it is necessary to examine the structural model. The fit of this model is better than the measurement model (chi-square $=184.20, \mathrm{p}=0.00 ; \mathrm{CFI}=.98 ; \mathrm{RMSEA}=.03 ; \mathrm{WRMR}=1.52)$, with the fit indices indicating proper fit. Figure 3 shows that biological sex has a direct effect on job dissatisfaction $\left(-.05^{* *}\right)$ and on workplace discrimination $(.32 * *)$. Furthermore, biological sex has an indirect effect on job dissatisfaction through workplace discrimination $(-.07 *)$. Therefore, results show that women are more likely to be dissatisfied with their job. Additionally, women are also more likely to experience workplace discrimination, which in turn negatively affects their job satisfaction. These findings support expectations of hypotheses 1, 2 and 5, and fail to support hypotheses 3 and 4 as the links between first generation and workplace discrimination and job satisfaction are not significant. Overall, this model suggests that workplace discrimination is not capable of removing the effects 
of biological sex on job satisfaction. However, the indirect effect is larger than the direct effect. This suggest that including workplace discrimination in the model is important.

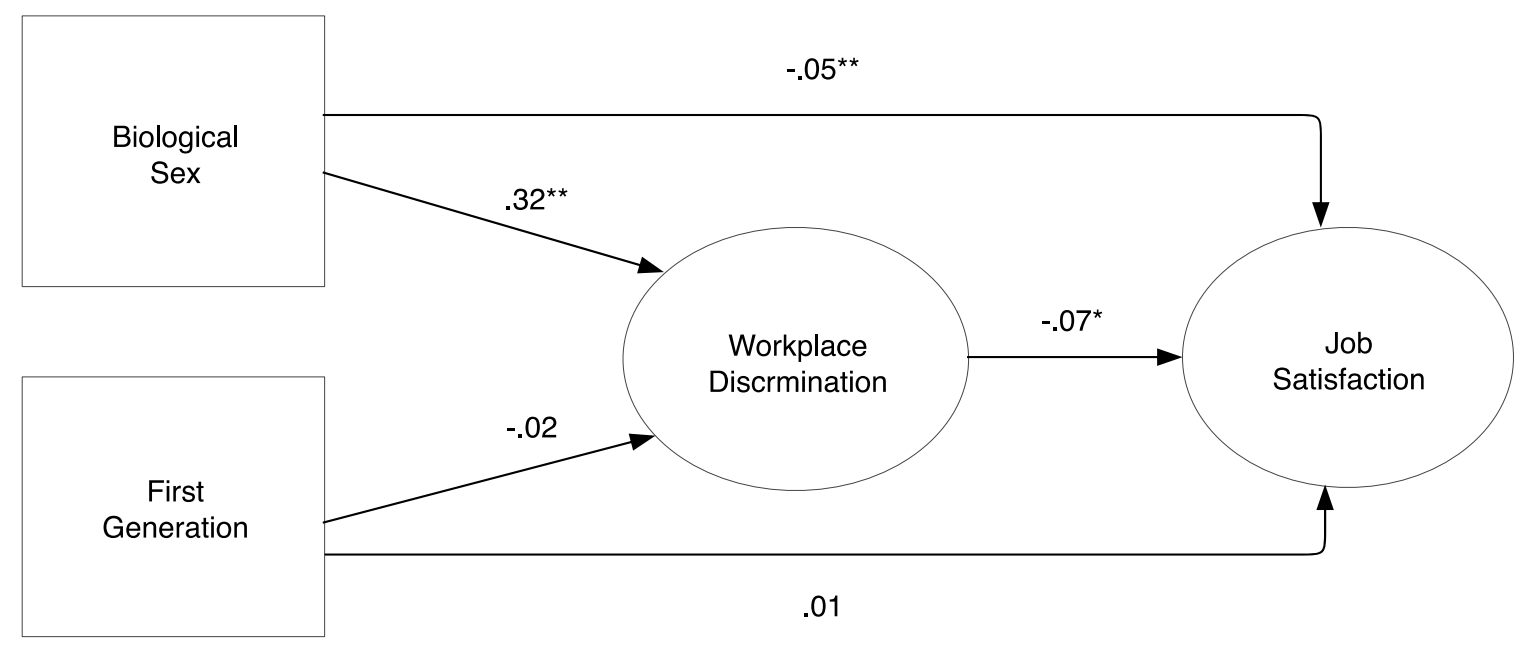

Figure 3. Direct and Indirect Effects Model

Step 5

Step 5 represents alternative models. The first alternative model (Figure 4) examines if biological sex, first generation and workplace discrimination have independent direct effects on job satisfaction. The model does not fit as well as previous models in this dissertation with the exception of the RMSEA (.06) (chi-square $=611.92$, $\mathrm{p}=0.00 ; \mathrm{CFI}=.91 ; \mathrm{RMSEA}=.06 ; \mathrm{WRMR}=2.98)$. Figure 4 shows that biological sex $(-$ $.22 * *)$ and workplace discrimination (-.12*) have independent significant links with job satisfaction. The link between biological sex and job satisfaction suggests that female lawyers are likely to be dissatisfied with their job. Additionally, the link between workplace discrimination and job dissatisfaction suggests that lawyers who experience 
one or more forms of discrimination are likely to feel dissatisfied with their job. Findings from this model support the hypotheses 1 and 5 and fail to support hypothesis 3 .

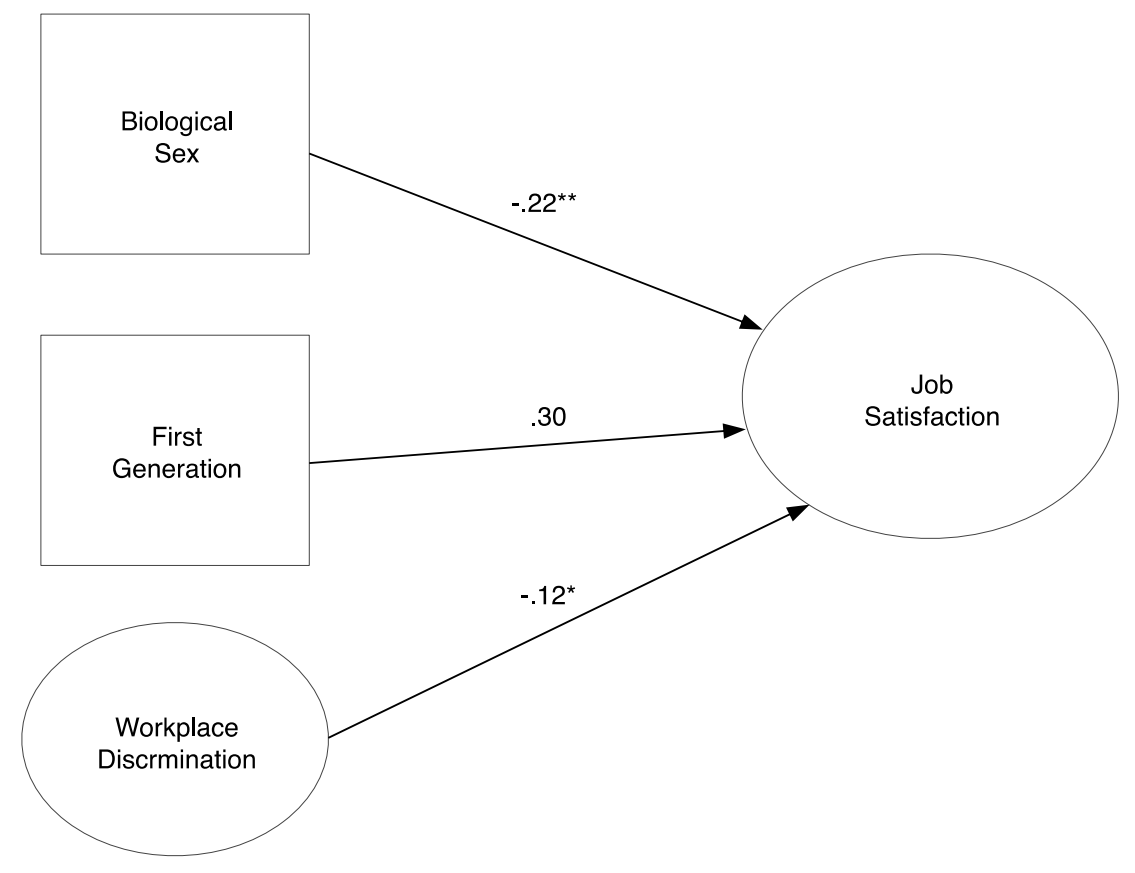

Figure 4. Alternative Direct Effects Model

The fourth model examines if biological sex and first generation have independent indirect effects with job satisfaction through workplace discrimination. The fit of this model is similar to the other models (chi-square $=144.98, \mathrm{p}=.000 ; \mathrm{CFI}=.98$; RMSEA $=.03$; WRMR $=1.67$ ), with the fit indices suggesting proper fit. Figure 5 shows that biological sex $\left(.33^{* *}\right)$ has a positive link with workplace discrimination and workplace discrimination has a negative link with job dissatisfaction $\left(-.09^{* *}\right)$. The link between biological sex and workplace discrimination suggests that female lawyers are likely to experience instances of workplace discrimination. Further, female lawyers are also more likely to be dissatisfied with their job. Results show an indirect effect of 
biological sex on job satisfaction that is negative (-.06**). This result suggests that workplace discrimination does mediate the link between biological sex and job satisfaction. Overall, this model supports the expectation of the present dissertation that the effect of biological sex on job satisfaction is mediated by workplace discrimination $(\mathrm{H} 2)$.

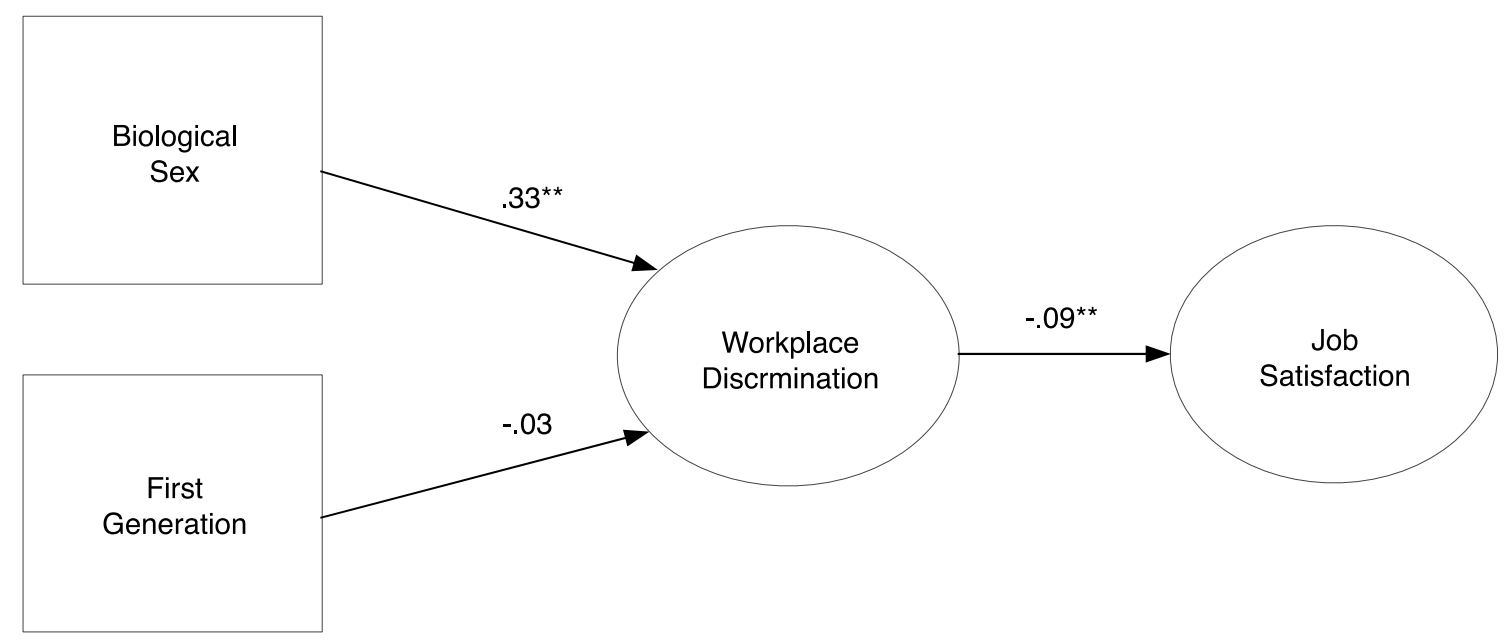

Note. indirect effect of biological sex on job satisfaction through workplace discrimination $\left(-.06^{* *}\right)$

Figure 5. Alternative Indirect Effects Model 


\section{CHAPTER V - DISCUSSION}

The present dissertation sough to examine the direct and indirect links between workplace discrimination, understood as strain, and job satisfaction among lawyers. Specifically, this dissertation analyzed biological sex and first-generation lawyers to determine such relationships. The motivation behind this research stemmed from the idea that for the past several decades, the legal profession has gone through an important transformation regarding women's representation. While women only accounted for 3\%

of the law school student population and 3\% of the legal profession in the early 1950's, in 2017, 47.3\% of law students being awarded a Juris Doctor were women (American Bar Association's Commission on Women, 2018). This change in the legal profession's demographics fed into the ongoing debates about what men and women should bring to the law.

In the 1960's, feminists argued that while there was a growing number of women participating in the legal profession, gender equality needed to be achieved for women to be successful in a men's world. However, in the 1970's this restricted vision was abandoned in favor of the argument that women had specific qualities that would benefit the legal field and allow to bring different perspectives on legal issues (Menkel-Meadow, 1989). Gilligan (1982) even argued that having more women in the legal field would inform change for the law to display a greater "ethic of care" and fairness (p. 73). 
Since research is sparse on the difference in job satisfaction between men and women lawyers, findings from this study make a modest contribution to the literature on the relationship between workplace discrimination and job satisfaction for lawyers.

Results from this dissertation present evidence of a direct relationship between workplace discrimination and job satisfaction. As workplace discrimination occurs when an employer or someone in the workplace takes unfavorable actions against an employee because of a characteristic that is protected by law (i.e. in this dissertation, biological sex), instances of workplace discrimination can be considered a strain (Agnew, 1992) which will ultimately increase job stress and job dissatisfaction (Jex \& Beehr, 1991; Spector 1997). Additionally, this dissertation provides some clarity regarding the difference between male and female lawyers and their experience with workplace discrimination and job satisfaction.

Echoing research published by Broidy and Agnew (1997), results from this dissertation show that men and women lawyers experience different amounts and types of strain in the workplace. Specifically, results showed that women lawyers are experiencing workplace discrimination at a higher rate than their male counterparts. The data showed that women are also likely to experience one or more forms of discrimination in the workplace. Those instances of workplace discrimination can take the form of experiencing demeaning comments or other types of harassment, or having desirable assignments being offered to their male colleagues. Thus, women lawyers are at a higher likelihood to experience what Agnew (2001) would define as noxious stimuli, or 
stressors in the workplace compared to men. Contrary to some of the literature arguing that men and women lawyers are equally satisfied with their job (Hall, 1995; Heinz et al., 1999), results showed that women lawyers are in fact more likely to be dissatisfied with their job compared to men.

Lastly, instances of straining workplace discrimination are causing women to be dissatisfied with their jobs at a higher rate. This finding is consistent with previous research showing that there is a link between discriminatory practices and negative emotions (Baron, 2004; Eitle, 2002; Eitle \& Turner, 2003; Higgins \& Gabbidon, 2009; Preston, 2006; walls, Chapple, \& Johnson, 2007). In this case, women lawyers are experiencing more instances of workplace discrimination compared to their male counterparts, which in turn is causing them to feel less satisfied with their job.

Results from this dissertation showed an absence of significant findings regarding the links between first-generation lawyers, workplace discrimination and job satisfaction. This is consistent with the literature, or lack thereof, on the topic. Indeed, Norgren's (2008) lecture at the Association of the Bar of the City of New York on the impact of workplace discrimination on job satisfaction for first-generation lawyers was one of few lectures or studies looking at first-generation lawyers. Specifically, this lecture emphasized first-generation women of color in the legal profession and how difficult it had been for this segment of the population to enter the legal workforce. From the absence of literature on the topic and the lack of significant findings in this dissertation, it may be possible to say that the data is simply not there to confirm or refute the idea that 
first-generation lawyers are experiencing higher workplace discrimination and job dissatisfaction compared to other lawyers. One last alternative model only focusing on criminal lawyers was created in this dissertation. Regrettably, that model did not converge. Consequently, this dissertation does not allow to shed light on whether criminal lawyers are more or less satisfied with their jobs compared to other lawyers practicing other types of law.

While the present dissertation is contributing to the criminological, legal and organizational literature, it is not without limitations. Firstly, using secondary data causes researchers to be at the mercy of a set of data that does not provide totally satisfactory measures of interests. Measuring the different facets of job satisfaction using the After the $J D$ data only partially satisfied our expectations. Secondly, the researchers who collected the data argued that, with a $71 \%$ response rate, their sample was representative of the national population of lawyers in the United States. They justify their claim by arguing that according to Census data, their sample matches the racial composition of young lawyers almost exactly. For gender, they compared their data with the American Bar Association and found another close match. They added a footnote to mention that in regard to gender, Census data was not appropriate to evaluate the gender makeup of their sample because of the very large number of women who had enrolled in law school in the late 1990's. While the data seems to be representative of the national population of lawyers, this is another example of being at the mercy of secondary data collection whose authors did not provide additional information for us to replicate their evaluation of the 
AJD participants to the Census and American Bar Association Data. In addition, this dissertation is lacking an emotional component that would explain feelings of strain exhibited by lawyers in the sample. Lastly, this dissertation uses a criminological theory and applied it to an organization. While this has been done in the past for organizations such as police departments, applying an organizational theory to this dissertation may lead to different results. Despite these limitations, this dissertation is the first study assessing the relationship between workplace discrimination and job satisfaction using a representative sample of the national population of lawyers in the United States.

The authors of the original study only conducted follow up interviews on $10 \%$ of the sample. Future research should try to interview every respondent who participated in the project. This would provide extensive knowledge about how lawyers truly feel about their job and how their feelings and perceptions may have evolved in the course of their first ten years of practice. Moreover, as this dissertation did not apply an organizational theory but rather applied a criminological theory to an organization, future research may want to look at the model through the lens of an organizational theory such as new institutionalism. Lastly, as the model focusing on criminal lawyers did not provide expected results, future research may want to investigate other types of law being practiced by attorneys in this sample to see if one type of law is more conducive to job satisfaction than another.

Despite the limitations inherent to this dissertation, results showed there is a link between workplace discrimination and job satisfaction for lawyers. Particularly, women 
lawyers are subject to higher workplace discrimination than their male counterparts. In turn, as workplace discrimination creates a strain in these individuals' lives, they also are at a higher rate of being dissatisfied with their job. Therefore, this dissertation shows that while we are living in a society that calls itself open-minded, egalitarian and prone to equality, even in higher level jobs such as law, bias still remains regarding how people are treated in organizations, especially regarding women lawyers. This portion of the population, while educated and trying to make the world a fairer and more just place, fighting for equality day in and day out in their job, are suffering from workplace discrimination and job dissatisfaction.

Further, as workplace discrimination impacts productivity, performance and job satisfaction, programs must be put in place to reduce the incidence of workplace discrimination, especially for women. As Cooper and Cartwright (1994) argued, rather than focusing on what organizations can do to help employees cope with stress, they should be proactive and implement strategies to eliminate instances of workplace stressors. Following the authors' advice and considering the results of this dissertation, lawyers' attitudes toward women need to change. Women should not be considered "outsiders" or less qualified. In addition, the same opportunities need to be created equally for men and women to inherit clients or get more resources to bring in business. Moreover, with the constant increase in knowledge and awareness about how lawyers, especially women, feel in their organization, more comprehensive workplace relations policies should be implemented to reduce or eliminate bullying and sexual harassment. 
To do so, law firms may want to follow the United States Equal Employment Opportunity Commission's (EEOC) recommendations to provide training to prevent harassment and discrimination in the workplace. For instance, EEOC published "Promising Practices for Preventing Harassment" which provides employers with five core principles to prevent and address harassment and strategies to reduce workplace harassment. Law firms should be familiar with those core principles to further prevent workplace harassment and discrimination. In addition, since October 2017, the EEOC has developed a new program and already trained almost 10,000 people on skills to enhance respect at work. Law firms should investigate the possibility to train its employees on developing respect in the workplace skills. In cases where harassment and discrimination have occurred at work, and to prevent job dissatisfaction, employees should familiarize themselves with the EEOC "What to do if you believe you have been harassed at work" which provides guidance and recommended steps to take if employees believe that they have been harassed at work.

Following training from EEOC will likely be associated with changes in policy to ensure that all employees are educated on the subject matter. It will also help reduce workplace discrimination and participate in the overall increase in job satisfaction. As a result, regular audits should be implemented to make sure that the organization is communicating and implementing new, discrimination-free workplace policies. Developing zero-tolerance policies will likely lead to a minimization of instances of workplace discrimination. Law firms can develop such policies by following Title VII of 
the Civil Rights Act along with specific state and federal laws which prohibit discriminatory practices. Overall, a change in policies, increased training to develop awareness, and a change in management's behavior in favor or reducing or eliminating workplace discrimination will likely contribute to an increase in women lawyers' feeling of job satisfaction.

The stress literature has compared the amounts of strain experienced by men and women and found that based on the "best samples and broadest inventories of stressors" (Broidy \& Agnew, 1997, p. 278), women are experiencing the same amount and even more strain than men. Furthermore, women have been found to classify these straining events as more stressful compared to men (Wagner \& Compas, 1990). Theoretical explanations of women's mistreatment in the workplace include prejudiced behaviors such as stereotypes, establishing social dominance, or favoritism (Sidanius \& Pratto, 2001). As a result, women experience stressors that fall under all three categories defined by Agnew in his General Strain Theory. Consistent with the literature on general strain theory, this dissertation shows that women in the legal profession are more likely to experience failures to achieve positively valued goals, the presentation of negatively valued stimuli, and the removal of positively valued stimuli compared to men. Combining these experiences with research on gender and emotion suggests that males and females who experience similar emotions may express them differently (De Coster \& Zito, 2010). In other words, not only do male and female experience different types of strain, they also differ in their emotional response to strain (Broidy \& Agnew, 1997). 
Thus, instances of workplace discrimination seem to intensify feelings of job dissatisfaction for women. Results from this dissertation showing that women lawyers who are experiencing greater instances of workplace discrimination are more likely to exhibit higher job dissatisfaction compared to men are consistent with the literature. Whether stereotypes in the legal profession led to women being perceived as less committed to the firm or less capable to fulfill their duties (Fuchs Epstein et al., 1995), results from this dissertation advocate for providing support, accommodations and rewards to women to encourage full participation, commitment and increase job satisfaction.

All in all, this dissertation provides evidence that female lawyers are at a higher likelihood of experiencing instances of workplace discrimination compared to their male colleagues. Whether these instances of workplace discrimination occur because of preconceived stereotypes, to establish male social dominance over females, or by simple favoritism of male versus female lawyers, women are likely to associate their experience with workplace discrimination with a decrease in job satisfaction. Women lawyers are less likely to be satisfied with their job compared to men lawyers and they are also more likely to experience workplace discrimination. As a result, these straining instances of workplace discrimination negatively impact women lawyers' job satisfaction. 


\section{REFERENCES}

Acker, J. (1990). Hierarchies, jobs, bodies: A theory of gendered organizations. Gender and Society, 4(2), 139-158.

Agnew, R. (1992). Foundation for a general strain theory of crime and delinquency. Criminology 30(1), 47-88.

Agnew, R. (2001). Building on the foundation of general strain theory: Specifying the types of strain most likely to lead to crime and delinquency. Journal of research in crime and delinquency 38(4), 319-361.

Allison, P. D. (2002). Missing Data. Sage Publications, Inc. Thousand Oaks: CA.

Altman, D. G., \& Bland, J. M. (2005). Standard deviations and standard errors. British Medical Journal, 331, 903.

American Bar Association Young Lawyers Division (1991). The state of the legal profession 1990. Chicago, IL.

American Bar Association Commission on Women in the Profession (2018). A Current Glance at Women in the Law. Chicago, IL.

Amponsah-Tawiah, K., Annor, F., \& Arthur, B. G. (2016). Linking commuting stress to job satisfaction and turnover intention: the mediating role of burnout. Journal of Workplace Behavioral Health, 31(2), 104-123. 
Anderson, T. W. (1957). Maximum likelihood estimates for a multivariate normal distribution when some observations are missing. Journal of the American Statistical Association, 52(278), 200-203.

Antecol, H., Barcus, V. E., \& Cobb-Clark, D. (2009). Gender-biased behavior at work: Exploring the relationship between sexual harassment and sex discrimination. Journal of Economic Psychology, 30(5), 782-792.

Applebaum, D., Fowler, S., Fiedler, N., Osinubi, O., \& Robson, M. (2010). The impact of environmental factors on nursing stress, job satisfaction, and turnover intention. Journal of Nursing Administration, 40(0), 323-328.

Asuero, A. G., Sayago, A., \& Gonzalez, A. G. (2006). The correlation coefficient: An overview. Critical Reviews in Analytical Chemistry, 36(1), 41-59.

Bagati, D. (2009). Women of color in U.S. law firms: Women of color in professional services series. New York, NY: Catalyst.

Bagozzi, R. P. (1982). A field investigation of causal relations among cognitions, affect, intentions and behavior. Journal of Marketing Research, 19(4), 562-584.

Bagozzi, R. P., \& Yi, Y. (2011). Specification, evaluation, and interpretation of structural equation models. Journal of the Academy of Marketing Science, 40(1), 8-34.

Benjamin, G. A., Darling, E. J., \& Sales, B. (1990). The prevalence of depression, alcohol use, and cocaine abuse among United States Lawyers. International Journal of Law and Psychiatry, 13(3), 233-246. 
Bennett, D. A. (2001). How can I deal with missing data in my study? Australia and New Zealand Journal of Public Health, 25(5), 464-469.

Benya F. F, Widnall S. E, Johnson, P. A. (2018). Sexual harassment of women: Climate, culture, and consequences in academic sciences, engineering, and medicine. Washington, DC: National Academies Press (US).

Bobbitt-Zeher, D. (2011). Gender discrimination at work: Connection gender stereotypes, institutional policies, and gender composition of workplace. Gender and Society, 25(6), 764-786.

Broidy, L., \& Agnew, R. (1997). Gender and crime: A general strain theory perspective. Journal of Research in Crime and Delinquency, 34(3), 275-306.

Campbell, D. T., \& Fiske, D. W. (1959). Convergent and discriminant validation by the multitrait-multimethod matrix. Psychological Bulletin, 56, 81-105.

Center for Work Life Law. (2006). Current law prohibits discrimination based on family responsibilities \& gender stereotyping. Retrieved from https://worklifelaw.org/publication/current-law-prohibits-discrimination-basedon-family-responsibilities-gender-stereotyping/

Chambers, D. L. (1989). Accomodation and satisfaction: Women and men lawyers and the balance of work and family. Law and Social Inquiry, 14(2), 251-287.

Cook, J. D., Hepworth, S. J., Wall, T. D., \& Warr, P. B. (1981). The experience of work. New York, NY: Academic Press. 
Cooper, C. L., \& Cartwright, S. (1994). Healthy mind; healthy organization - a proactive approach to occupational stress. Human Relations, 47(4), 455-471.

Cortina, J. M. (1993). What is coefficient alpha? An examination of theory and applications. Journal of Applied Psychology, 78(1), 98-104.

De Coster, S., \& Zito, R. C. (2010). Gender and General Strain Theory: The gendering of emotional experiences and expressions. Journal of Contemporary Criminal Justice, 26(2), 224-245.

Deitch, E. A., Barsky, A., Butz, R. M., Chan, S., Brief, A. P., \& Bradley, J. C. (2003). Subtle yet significant: The existence and impact of everyday racial discrimination in the workplace. Human Relations, 56(11), 1299-1324.

Delgado, R., \& Stefancic, J. (2007). Can Lawyers Find Happiness? Syracuse Law Review, 58(2), 241-259.

Diener, E., Emmons, R. A., Larsen, R. J., \& Griffin, S. (1985). The Satisfaction with Life Scale. Journal of Personality Assessment, 49, 71-75.

Dinovitzer, R., \& Garth, B. G. (2007). Lawyer satisfaction with the process of structuring legal careers. Law and Society Review, 41(1), 1-50.

Dinovitzer, R., Garth, B. G., Sander, R., Sterling, J., \& Wilder, G. Z. (2004). After the JD: First results of a national study of legal careers. Chicago, IL: NALP Foundation for Law Career Research and Education and the American Bar Foundation. 
Dong, Y., \& Peng, C-Y. J. (2013). Principled missing data methods for reserachers. SpringerPlus, 2(1), 222-239.

Dowell, R. S., \& Fortgang, J. (2019). Cleaning solutions for the toxic workplace. American Bar Association. Retrieved from https://www.americanbar.org/groups/gpsolo/publications/gp_solo/2011/january_f ebruary/cleaning_solutions_for_thetoxicworkplace/

Drogan, E. (1991). Alcoholism in the legal profession: Psychological and legal perspectives and interventions, Law and Psychiatry Review, 15, 117-127.

Enders, C. K. (2001a). Applied Missing Data Analysis. New York, NY: The Guildford Press.

Enders, C. K. (2001b). The impact of nonnormality on full information maximum likelihood estimation for structural equation models with missing data. Psychological Methods, 6(4), 352-370.

Enders, C. K., \& Bandalos, D. L. (2001). The relative performance of full information maximum likelihood estimation for missing data in structural equation models. Structural Equation Modeling, 8(3), 430-457.

Evans, A. (2001). Lawyers' perceptions of their values: An empirical assessment of Monash University graduates in Law, 1980-1998. Legal Education Review, 12(2), 209-266. 
Fuchs Epstein, C., Sauté, R., Oglensky, B., \& Gever, M. (1995). Glass ceilings and open doors: Women's advancement in the legal profession. Fordham Law Review, 64(2), 291-449.

Gallup, Inc (2007). State of the American Workplace. Retrieved from https://news.gallup.com/topic/report.aspx

Garth, B. G., Sterling, J., \& Sander, R. (2013). After the JD - Wave 1: A Longitudinal Study of Legal Careers in Transition Data Collection: May 2002-May 2003, United States. Ann Arbor, MI: Inter-university Consortium for Political and Social Research [distributor]. Retrieved from: https://doi.org/10.3886/ICPSR26302.v2

Gibbs, J. J., Giever, D. M., \& Higgins, G. E. (2003). A test of Gottfredson and Hirschi's general theory using structural equation modeling. Criminal Justice and Behavior, $30,441-458$.

Gilligan, C. (1982). In a different voice: Psychological theory and women's development. Cambridge, MA: Harvard University Press.

Graham, J. W. (2009). Missing data analysis: Making it work in the real world. Annual Review of Psychology, 60, 549-576.

Hagan, F. E. (1982). Research methods in criminal justice and criminology. New York, NY: Macmillan.

Hagan, J., \& Kay, F. (1995). Gender in practice: A study of lawyers' lives. New York, NY: Oxford University Press. 
Hagan, J., \& Kay, F. (2007). Even lawyers get the blues: Gender, depression, and job satisfaction in legal practice. Law \& Society Review, 41(1), 51-78.

Hall, D. L. (1995). Job satisfaction among male and female public defense attorneys. The Justice System Journal, 18(2), 121-139.

Heinz, J. P., Hull, K. E., \& Harter, A. A. (1999). Lawyers and their discontents: Findings from a survey of the Chicago Bar. Indiana Law Journal, 74(3), 735-758.

Homans, G. C. (1961). Social Behavior: Its Elementary Forms. New York: Harcourt, Brace \& World.

Hu, L. T., \& Bentler, P. M. (1995). Evaluating model fit. In R. H. Hoyle (Ed.), Structural equation modeling: Concepts, issues, and applications (pp. 76-99). Thousand Oaks, CA: Sage.

Hu, L. T., \& Bentler, P. M. (1999). Cutoof criteria for fit indexes in covariance structure analysis: Conventional criteria versus new laternatices. Structural Equation Modeling, 6, 1-55.

Hull, K. E. (1999). The paradox of the contended female lawyer. Law and Society Review, 33, 687-702.

Johnson, S., Cooper, C., Cartwrigth, S., Donald, I., Tyalor, P. \& Millet, C. (2005). The experience of work-related stress across occupations. Journal of Managerial Psychology, 20(2), 178-187.

Kay, F. M., \& Gorman, E. (2008). Women in the legal profession. Annual Review of Law and Social Science, 4, 299-332. 
Kay, F. M., \& Hagan, J. (2003). Buidling trust: Social capital, distributive justice, and loyalty to the firm. Law and Social Inquiry, 28(2), 483-519.

Kelloway, E. K. (1998). Using LISREL for structural equation modeling: A researcher's guide. Thousand Oaks, CA: Sage.

Kline, R. B. (1998). Principles and practices of structural equation modeling. New York, NY: Guilford.

Kline, R. B. (2004). Principles and practices of structural equation modeling. New York, NY: Guildford.

Kronman, A. T. (1993). The lost lawyer: failing ideals of the legal profession. Cambridge, MA: Belknap Press of Harvard University Press.

Laband, D. N., \& Lentz, B. F. (1998). The effects of sexual harassment on job satisfaction, earnings, and turnover among female lawyers. Industrial and Labor Relations Review, 51(4), 594-607.

Little, R. J. A., \& Rubin, D. B. (2002). Statistical Analysis with Missing Data (2 ${ }^{\text {nd }}$ ed.). Hoboken, NJ: John Wiley \& Sons, Inc.

Locke, E. A. (1969). What is job satisfaction? Organizational Behavior and Human Performance, 4, 309-336.

Maslach, C., Jackson, S. (1978). Lawyer burn out. Barrister, 5, 8.

McLaughlin, H., Uggen, C., \& Blackstone, A. (2017). The economic and career effects of sexual harassment on working women. Gender \& Society, 31(3), 333-358. 
Menkel-Meadow, C. (1989). Exploring a research agenda of the feminization of the legal profession: theories of gender and social change. Law \& Social Inquiry, 14(2), 289-319.

Mertler, C. A., \& Vannatta, R. A. (2016). Advanced and multivariate statistical methods: Practical application and interpretation (6th ed.). New York, NY: Routledge.

Miller, C. T., \& Kaiser, C. R. (2001). A theoretical perspective on coping with stigma. Journal of Social Issue, 57, 73-92.

Moon, M. M., \& Johnson, C. L. (2012). The influence of occupational strain on organizational commitment among police: A general strain theory approach. Journal of Criminal Justice, 40(3), 249-258.

National Association of Women Judges (2019). 2019 US State Court Women Judges. Retrieved from https://www.nawj.org/statistics/2019-us-state-court-womenjudges

National Women's Law Center. (2016). Women in the Federal Judiciary: Still A Long Way to Go. Retrieved from https://nwlc.org/resources/women-federal-judiciarystill-long-way-go/

New York City Bar Assocation (2000). Task Force on Lawyers' Quality of Life Report (Report No 55). New York, NY: New York City Bar Assocation.

North Carolina Bar Association. (1991). Report of the Quality of Life Task Force and Recommendations 4. 
Pavot, W., \& Diener, E. (2008). The satisfaction with life scale and the emerging construct of life satisfaction.

Piquero, N. L. (2005). Understanding police stress and coping resoires across gender: A look toward general strain theory. In H. Copes (Ed.), Policing and Stress (pp. 126-139). Upper Saddle River, NJ: Prentice Hall.

Reichman, N. J., \& Sterling, J. S. (2002). Recasting the brass ring: deconstructing and reconstructing workplace opportunities for women lawyers. Capital University Law Review, 29, 923-977.

Rhode, D. L. (1988). Perspectives on professional women. Stanford Law Review, 40(5), 1163-1207.

Rhode, D. L. (2001). The unfinished agenda: Women in the legal profession. Chicago, IL: ABA Commission of Women in the Profession.

Rhode, D. L. (2011). From platitudes to priorities: Diversity and gender equity in law firms. The Georgetown Journal of Legal Ethics, 24, 1041-1077.

Rode, J. C. (2004). Job satisfaction and life satisfaction revisited: A longitudinal test of an integrated model. Human Relations, 57(9), 1205-1230.

Rubin, D. B. (1976). Inference and missing data. Biometrika Trust, 63(3), 581-592.

Saari, L. M., \& Judge, T. A. (2004). Employee attitudes and job satisfaction. Human Resource Management, 23(4), 395-407.

Schafer, J. L. (1999). Multiple imputation: A primer. Statistical Methods in Medical Research, 8(1), 3-15. 
Schafer, J. L., \& Graham, J. W. (2002). Missing data: Our view of the state of the art. Psychological Methods, 7(2), 147-177.

Schiltz, P. J. (1999). On being happy, healthy, and ethical member of an unhappy unhealthy, and unethical profession. Vanderbilt Law Review, 52, 871-951.

Schneider, K. T., Swan, S., \& Fitzgerald, I. F. (1997). Job-related and psychological effects of sexual harassment in the workplace: Empirical evidence from two organizations. Journal of Applied Psychology, 82, 401-415.

Schultz, U., \& Shaw, G. (2003). Women in the world's legal profession. London, UK: Bloomsbury Publishing.

Sheskin, D. J. (2007). Handbook of parametric and nonparametric statistical procedures ( $4^{\text {th }}$ ed.). Boca Raton, FL: Chapman \& Hall/CRC.

Sidanius, J., \& Pratto, F. (2001). Social dominance: An intergroup theory of social hierarchy and oppression. Cambridge, UK: Cambridge University Press.

Smith, P. C., Kendall, L. M., \& Hulin, C. L. (1969). The measurement of satisfaction in work and retirement. Chicago, IL: Rand McNally \& Company.

Spector, P. E. (1997). Job satisfaction: Application, assessment, causes and consequences. Thousand Oaks, CA: SAGE Publications, Inc.

Stubbe, J. H., Posthuma, D., Boomsma, D. I., \& De Geus, E. J. C. (2005). Heritability of life satisfaction in adults: A twin-family study. Psychological Medicine, 35, 1-8. 
Swim, J. K., Hyers, I. I., Cohen, L. L., \& Ferguson, M. J. (2001). Everyday sexism: Evidence for its incidence, nature, and psychological impact from three daily diary studies. Journal of Social Issues, 57, 31-53.

Tabachnick, B. G., \& Fidell, L. S. (2012). Using Multivariate Statistics (6 ${ }^{\text {th }}$ ed). London, UK: Pearson.

Tavakol, M., \& Dennick, R. (2011). Making sense of Cronbach's alpha. International Journal of Medical Education, 2, 53-55.

Taylor, P., Mcloughlin, C., Meyer, D., \& Brooke, E. (2013). Everyday discrimination in the workplace, job satisfaction and psychological wellbeing: age differences and moderating variables.

Teitelbaum L. E., Lopez, A. S., \& Jenkins, J. (1991). Gender, legal education, and legal careers. Journal of Legal Education, 41, 443-481.

United States Equal Employment Opportunity Commission (2017). Promising Practices for Preventing Harassment. Washington, DC: U.S. Eqiual Employment Opportunity Commission. Retrieved from https://www.eeoc.gov/eeoc/publications/promising-practices.cfm United States Equal Employment Opportunity Commission (2017). What You Should Know: What to Do if You Believe You Have Been Harassed as Work. Washington, DC: U.S. Equal Employment Opportunity Commission. Retrieved from https://www.eeoc.gov/eeoc/newsroom/wysk/harassed_at_work.cfm 
United States Equal Employment Opportunity Commission. (2017). Respectful

Workplaces. Washington, DC: U.S. Equal Employment Opportunity Commission.

Wagner, B. M., \& Compas, B. E. (1990). Gender, intrumentality, and expressivity: Moderators of the relatino between stress and psychological symptoms during adolescence. American journal of Community Psychology, 18, 383-406.

Wallace, J. E. (1999). Work-to-nonwork conflcit among married male and female lawyers. Journal of Organizational Behavior, 20, 797-816.

Walters, G. D. (2015). The deicsion to commit crime: Rational or nonrational. Criminology, Criminal Justice Law, \& Society, 16(3), 1-18.

Walsh, C. (2017). The engaged employee blueprint: Build a workplave culture where employees thrive. Victoria, Canada: FriesenPress.

Warr, P., \& Payne, R. (1983). Social class and reported changes in behavuoir after job loss. Journal of Applied Social Psychology, 13(3), 206-222.

Wexley, K. N., Alexander, R. A., Greenawalt, J. P., \& Couch, M. A. (1980). Attitudinal congruence and similarity as related to interpersonal evaluations in managersubordinate dyads. The Academy of Management Journal, 23(2), 320-330.

Williams, J. C., Bornstein, S., Reddy, D., \& Williams, B. A. (2007). Law firms as defendants: Family responsibilties discrimination in legal workplaces. Pepperdine Law Review, 34, 393-416. 
Wolf, M. G. (1970). Need gratification theory: A theoretical reformulation of job satisfaction/dissatisfaction and job motivation. Journal of Applied Psychology, 77, 910-917.

Woodson, K. (2016). Human capital discrimination, law firm inequality, and the limits of Title VII. Cardozo Law Review, 38, 183-229. 


\section{CURRICULUM VITA}

NAME: Caroline Isabelle Jalain

ADDRESS: Department of Criminal Justice

2301 S. $3^{\text {rd }}$ St., Brigman Hall 102E

University of Louisville

Louisville, KY 40292

DOB: $\quad$ Martigues, France - June 4, 1990

EDUCATION

\& TRAINING: $\quad$ B.S., European Law

University of Orleans (France)

2008-2011

L.L.M, International Business Law

University Paris 1 Pantheon Sorbonne (France)

2011-2012

M.A., Criminal Justice

The University of Southern Mississippi

2012-2014

Ph.D., Criminal Justice

The University of Louisville

2017-2020

AWARDS: Graduate Student Regional Research Conference Certificate The University of Louisville

2019

School of Interdisciplinary and Graduate Studies Certificate of Frequent Professional Development, Life Skills, Academic Development, and Networking Participation Certificate

The University of Louisville 2018 
Doctoral Summit Certificate of Completion

Academy of Criminal Justice Sciences

2017

PROFESSIONAL SOCIETIES: $\quad$ Academy of Criminal Justice Sciences

American Society of Criminology

Southern Criminal Justice Association

Midwestern Criminal Justice Association

REFEREED PUBLICATIONS: $\quad$ Jalain, C. I. \& Grossi, E. L. (2019). Take a load of Fanny: Peer mentors in veterans treatment courts. Criminal Justice Policy Review. https://doi.org/10.1177/0887403419880289

Jalain, C. I. (2018). The Life and the Adventures of a Haunted Convict. Book Review. Journal of Criminal Justice Education, 30(1), 156-158. https://doi.org/10.1080/10511253.2018.1482361

\section{NATIONAL MEETING PRESENTATIONS:}

The Impact of Pre-Service and Service-Related Experiences on Sexual Assault Perpetration Among Service Members with Dr. Viviana Andreescu, Dr. Elizabeth Grossi, Laura Fortin, Academy of Criminal Justice Sciences (ACJS, San Antonio, TX) (Conference canceled due to Covid19). March 2020

Measuring Job Satisfaction of Lawyers: A Confirmatory Factor Analysis Approach with Dr. George E. Higgins, American Society of Criminology (ASC, San Francisco, CA). November 2019

The Effect of Adult Mental Health Courts on Recidivism: A MetaAnalysis with Dr. Paul A. Lucas, Southern Criminal Justice Association (SCJA, Nashville, TN). September 2019

Court Performance and Court Culture: Assessing Differences between Prosecutors and Public Defenders Using Structural Equation Modeling with Dr. George E. Higgins, Academy of Criminal Justice Sciences (ACJS, Baltimore, MD). March 2019

Fear of Violent Crime in France: A Replication Study of the Relationship between Ethnicity and Public Perception of Safety with Dr. George E. 
Higgins, American Society of Criminology (ASC, Atlanta, GA). November 2018

Veterans Treatment Courts: An analysis of mentor programs with Dr. Elizabeth L. Grossi, Academy of Criminal Justice Sciences (ACJS, New Orleans, LA). February 2018

Juvenile Offenders on Trial: A Preliminary Examination of Juvenile Defender Perceptions of Culpability, Mitigation and Mental Health with Dr. Lisa Nored, American Society of Criminology (ASC, New Orleans, LA). November 2016

Presidential Rhetoric as Crime Control Theater: The Case of Cybercrime with Dr. Joshua B. Hill and Dr. Nancy E. Marion, Academy of Criminal Justice Sciences (ACJS Denver, CO). March 2016

INVITED PRESENTATIONS: CJ 596, Social and Restorative Justice, The University of Louisville

March 2019

CJ 751, Advanced Statistical Computer

Applications for Criminal Justice, The University of Louisville

February 2019

CJ 202, Corrections in the U.S., The University of Louisville

December 2017

CJ 480, Crime and the Media, The University of Southern Mississippi

February 2016

CJ 325, Criminal Justice Theory, The University of Southern Mississippi

February 2016

CJ 426, Comparative Criminal Justice, The University of Southern Mississippi February 2016

CJ 325, Criminal Justice Theory, The University of 
Southern Mississippi

November 2015

CJ 435, Organization and Management of Criminal Justice, The University of Southern Mississippi September 2015

Law and Public Safety, Hattiesburg High School, Hattiesburg, MS

September 2015 